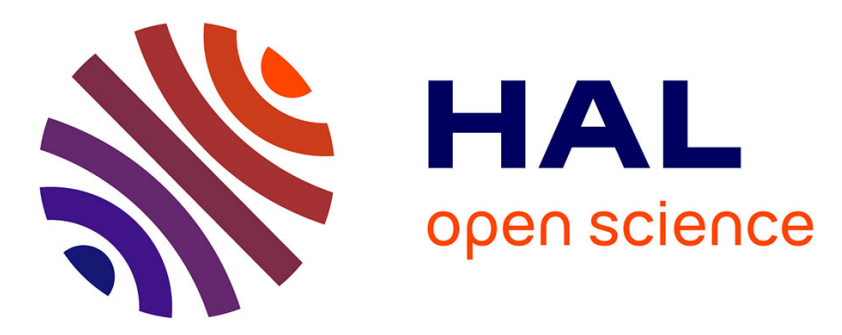

\title{
Eocene and Oligocene basins and ridges of the Coral Sea-New Caledonia region: Tectonic link between Melanesia, Fiji, and Zealandia
}

Nick Mortimer, Phillip Gans, J. Michael Palin, Richard Herzer, Michel Monzier, Bernard Pelletier

\section{To cite this version:}

Nick Mortimer, Phillip Gans, J. Michael Palin, Richard Herzer, Michel Monzier, et al.. Eocene and Oligocene basins and ridges of the Coral Sea-New Caledonia region: Tectonic link between Melanesia, Fiji, and Zealandia. Tectonics, 2014, 33 (7), pp.1386 - 1407. 10.1002/2014TC003598 . hal-01859820

\section{HAL Id: hal-01859820 https://hal.science/hal-01859820}

Submitted on 20 Sep 2021

HAL is a multi-disciplinary open access archive for the deposit and dissemination of scientific research documents, whether they are published or not. The documents may come from teaching and research institutions in France or abroad, or from public or private research centers.
L'archive ouverte pluridisciplinaire HAL, est destinée au dépôt et à la diffusion de documents scientifiques de niveau recherche, publiés ou non, émanant des établissements d'enseignement et de recherche français ou étrangers, des laboratoires publics ou privés.

$$
\text { Copyright }
$$




\section{Tectonics}

\section{RESEARCH ARTICLE}

10.1002/2014TC003598

Key Points:

- With care, ultralow-K/Ca material can give interpretable Ar-Ar ages

- The South Rennell Trough is a 28-29 Ma fossil spreading center

- Several Eocene to Miocene back-arc basins lie between Melanesia and Zealandia

Supporting Information:

- Readme

- Table S1

- Table S2

- Table S3

Correspondence to:

N. Mortimer,

n.mortimer@gns.cri.nz

Citation:

Mortimer, N., P. B. Gans, J. M. Palin, R. H. Herzer, B. Pelletier, and M. Monzier (2014), Eocene and Oligocene basins and ridges of the Coral Sea-New Caledonia region: Tectonic link between Melanesia, Fiji, and Zealandia, Tectonics, 33, 1386-1407, doi:10.1002/ 2014 TC003598.

Received 27 MAR 2014 Accepted 17 JUN 2014 Accepted article online 25 JUN 2014 Published online 14 JUL 2014

\section{Eocene and Oligocene basins and ridges of the Coral Sea-New Caledonia region: Tectonic link between Melanesia, Fiji, and Zealandia}

\author{
Nick Mortimer ${ }^{1}$, Phillip B. Gans ${ }^{2}$, J. Michael Palin³ ${ }^{3}$ Richard H. Herzer ${ }^{4}$, Bernard Pelletier ${ }^{5}$, \\ and Michel Monzier ${ }^{5,6}$
}

${ }^{1}$ GNS Science, Dunedin, New Zealand, ${ }^{2}$ Department of Geological Sciences, University of California, Santa Barbara, California, USA, ${ }^{3}$ Department of Geology, University of Otago, Dunedin, New Zealand, ${ }^{4}$ GNS Science, Lower Hutt, New Zealand, ${ }^{5}$ Institut de Recherche pour le Développement, Nouméa, New Caledonia, ${ }^{6}$ Deceased 2 September 2004

Abstract This paper presents 34 geochemical analyses, $24 \mathrm{Ar}-\mathrm{Ar}$ ages, and two U-Pb ages of igneous rocks from the back-arc basins and submarine ridges in the Coral Sea-New Caledonia region. The D'Entrecasteaux Ridge is a composite structural feature. Primitive arc tholeiites of Eocene age (34-56 Ma) are present along a $200 \mathrm{~km}$ length of the ridge and arguably were part of the initial line of subduction inception between Fiji and the Marianas; substantial Eocene arc edifices are only evident at the eastern end where Bougainville Guyot andesite breccias are dated at 40 $2 \mathrm{Ma}$. The South Rennell Trough is confidently identified as a 28-29 Ma (early Oligocene) fossil spreading ridge, and hence, the flanking Santa Cruz and D'Entrecasteaux basins belong in the group of SW Pacific Eocene-Early Miocene back-arc basins that include the Solomon Sea, North Loyalty, and South Fiji basins. The rate and duration of spreading in the North Loyalty Basin is revised to $43 \mathrm{~mm} / \mathrm{yr}$ between 28 and $44 \mathrm{Ma}$, longer and faster than previously recognized. The direction of its opening was to the southeast, that is, parallel to the continent-ocean boundary and perpendicular to the direction of coeval New Caledonia ophiolite emplacement. Medium- and high-K alkaline lavas of 23-25 Ma (late Oligocene) age on the northern Norfolk Ridge are an additional magmatic response to Pacific trench rollback.

\section{Introduction}

The southwest Pacific Ocean contains an array of active and extinct subduction-related volcanic chains and submarine basins and back-arc basins floored by oceanic crust. All of these lie east of the continent of Australia and most lie north of the continent of Zealandia (Figure 1). The basins can be divided into three groups based on position with respect to Australia, age, complexity, and level of knowledge:

1. Late Cretaceous-early Eocene ocean basins are the Tasman Sea, western Coral Sea, and Louisiade Trough. These lie adjacent to Australia and have relatively simple and well-known opening histories [Weissel and Watts, 1979; Gaina et al., 1999].

2. Late Eocene-early Miocene basins include the Solomon Sea Basin, North Loyalty Basin, South Fiji Basin, Norfolk Basin, and New Caledonia Trough. These have at least been investigated in reconnaissance to establish their age, although multiple interpretations exist for their age and development [e.g., Crawford et al., 2003; Sdrolias et al., 2003; Mortimer et al., 2007; Herzer et al., 2011].

3. Late Miocene-Holocene basins are the Woodlark Basin, North Fiji Basin, Lau Basin, and Havre Trough. They generally lie to the east and north of the region; despite complex spreading patterns, their age and geological history is relatively well known [e.g., Hall, 2002].

Far less is known about the Santa Cruz and D'Entrecasteaux basins, the South Rennell Trough, and the Rennell and D'Entrecasteaux ridges of the eastern Coral Sea region (Figure 1). The only data on these features were gathered in the 1970s by French GEORSTOM cruises [Monzier, 1976; Daniel et al., 1976, 1977; Larue et al., 1977; Récy and Dupont, 1982] and by two Ocean Drilling Program (ODP) holes at the east end of the D'Entrecasteaux Ridge [Baker et al., 1994; Coltorti et al., 1994]. In the last few decades, there have been no expeditions or data gathering in the region, although the Sandwell and Smith [1997] satellite gravity maps have provided a new framework for reexamination. In the absence of new data, the 1970s interpretations of the Rennell, Santa Cruz, and D'Entrecasteaux basins either have been recycled into SW Pacific syntheses [e.g., Schellart et al., 2006] or largely ignored [e.g., Hall, 2002; Crawford et al., 2003; Whattam et al., 2008]. 


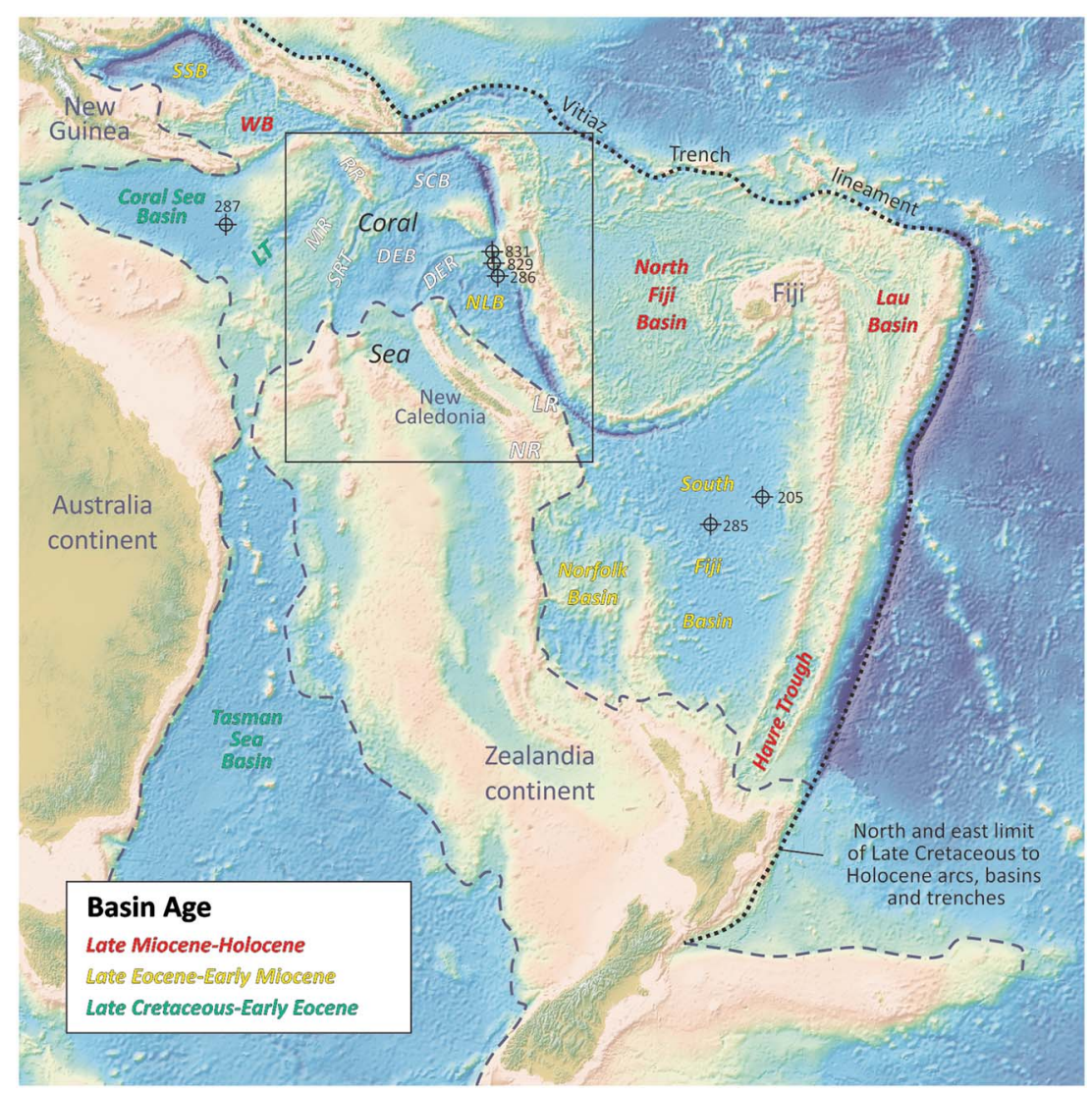

Figure 1. Late Cretaceous to Holocene back-arc basins and arcs of the SW Pacific. Three digit numbers refer to Deep Sea Drilling Project and Ocean Drilling Program boreholes. SSB = Solomon Sea Basin, WB = Woodlark Basin, LT = Louisiade Trough, $\mathrm{RR}=$ Rennell Ridge, $\mathrm{MR}=$ Mellish Rise, SRT = South Rennell Trough, $\mathrm{SCB}=$ Santa Cruz Basin, DEB = D'Entrecasteaux Basin, $\mathrm{DER}=\mathrm{D}^{\prime}$ Entrecasteaux Ridge, NLB $=$ North Loyalty Basin, $\mathrm{LR}=$ Loyalty Ridge, NR = Norfolk Ridge. Vitiaz Trench lineament after Pelletier and Auzende [1996]. The box shows area of Figure 2.

The current situation is well illustrated by Collot et al. [2011] whose SW Pacific map indicates an age for every ocean basin in the SW Pacific except the Rennell, Santa Cruz, and D'Entrecasteaux basins.

The purpose of this paper is to report new geochemical and geochronological analyses and interpretations of rocks, mainly basalts, dredged from the eastern Coral Sea region with some additional samples from the North Loyalty Basin and the Loyalty and North Norfolk ridges (Figures 2 and 3). Most of the data in this paper are modern analyses and dating of material dredged on the GEORSTOM cruises of Daniel et al. [1976, 1977], Bitoun and Récy [1982], and Maillet et al. [1983], supplemented by material from submersible dives in the Vanuatu Trench [Monzier, 1993; Monzier et al., 1989] and from the ODP holes at the east end of the D'Entrecasteaux Ridge [Baker et al., 1994; Coltorti et al., 1994].

Our results drastically improve our knowledge of the age and tectonic development of the region, particularly in the context of SW Pacific basin age, Eocene subduction initiation, Paleogene arc formation, and Oligocene rifting. A considerable effort was put into the Ar-Ar dating of low- $\mathrm{K} / \mathrm{Ca}$ plagioclases from basalts, and we explain in some detail our approach to this.

\section{Geological Framework and Previous Work}

The age, polarity, sequential development, and relationship of the Rennell Ridge, Santa Cruz Basin, South Rennell Trough, and D'Entrecasteaux Basin to neighboring features are very much speculative. Based on regional considerations, Schellart et al. [2006] considered the South Rennell Trough, Santa Cruz Basin, and D'Entrecasteaux Basin as Late Cretaceous to Paleocene spreading features. 


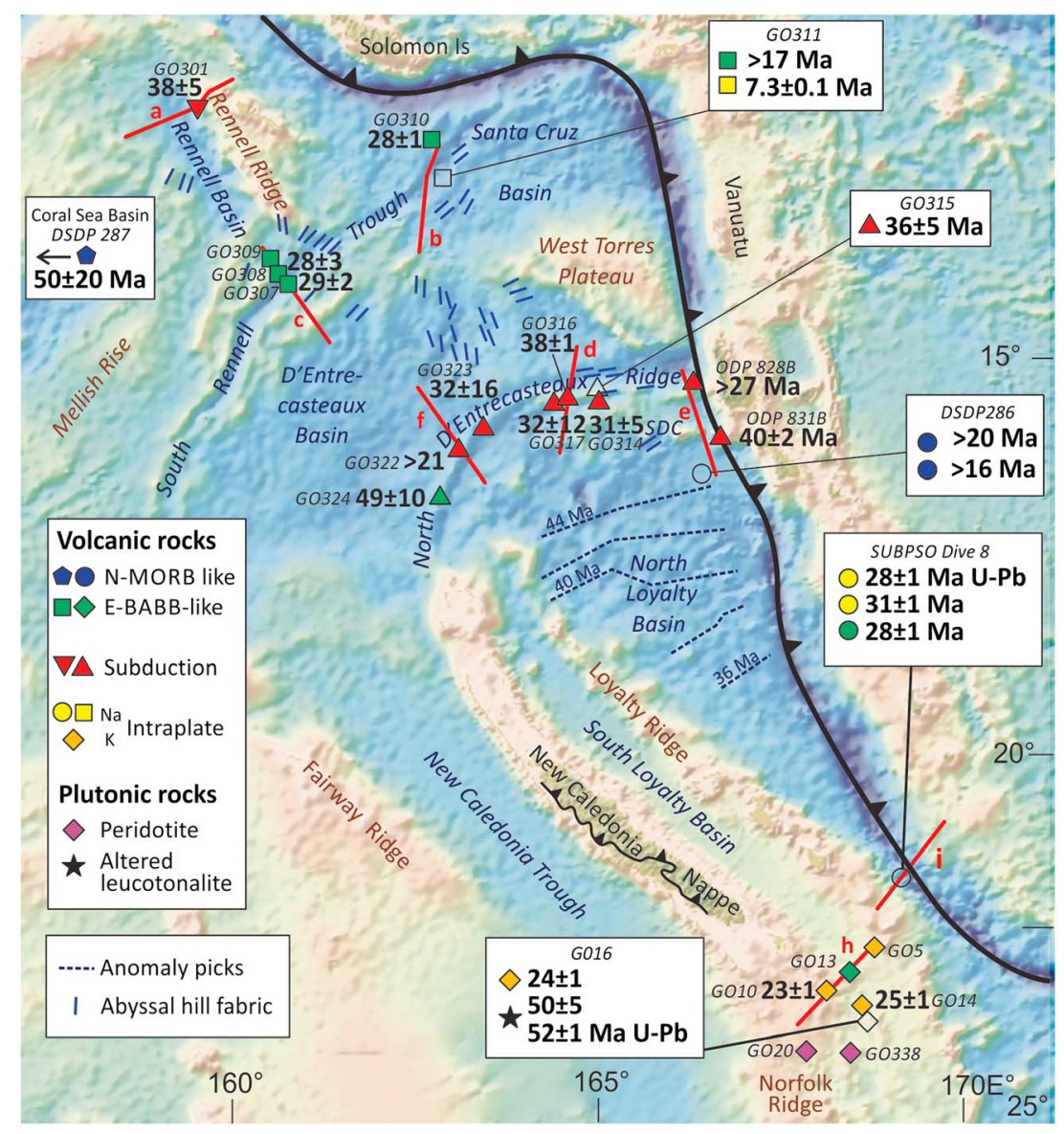

Figure 2. Sample location map summarizing new age and compositional data of lavas from GEORSTOM cruises, SUBPSO 8 dive sites, and DSDP 286 and 287 and ODP 829 and 831 drill holes. For details of cross sections a-g see Figure 3. $\mathrm{MORB}=$ mid-ocean ridge basalt, $\mathrm{BABB}=$ back-arc basin basalt. Abyssal hill fabrics obtained from unpublished ship transit data Kiwi10RR, BMRG07MV, EW0002, and Kaonou 07/1996 sourced through http://www.geomapapp.org [Ryan et al., 2009; B. Pelletier, unpublished data, 2014].

\subsection{Rennell Ridge and Basin}

The Rennell Ridge [Daniel et al., 1978; Récy and Dupont, 1982] is an irregular-shaped 200 by 70 km long feature. The highest point is Rennell Island which is a dolomitized coral reef which dates back to the middle Miocene [Bourrouilh et al., 1976]. The Rennell Ridge has been interpreted as an island arc with the Rennell Basin as its paleotrench (Figure 3a) [Récy et al., 1975; Coleman and Packham, 1976]; however, Coleman and Packham [1976] additionally suggested that the ridge could be a continental block that once occupied a position between New Guinea and New Caledonia.

\subsection{South Rennell Trough and Adjacent Basins}

The South Rennell Trough is a approximately $700 \mathrm{~km}$ long by $30 \mathrm{~km}$ wide feature, whose floor is up to $5000 \mathrm{~m}$ below sea level (Figures 2, 3b, and 3c). The D'Entrecasteaux Basin lies to the southeast and the Santa Cruz Basin to the northeast. It was interpreted by Larue et al. [1975, 1977] and Daniel et al. [1978] as a relict spreading ridge, based on its geometry, heat flow measurements, and on provisional magnetic anomaly picks. In contrast, Landmesser et al. [1975], Terrill [1975], and Coleman and Packham [1976] interpreted the Trough as a fracture zone controlled by the same Euler poles as fracture zones in the Tasman Sea Basin and Coral Sea Basin.

\subsection{D'Entrecasteaux Ridge}

The D'Entrecasteaux Ridge is a approximately $600 \mathrm{~km}$ long composite intraoceanic feature that changes strike by $90^{\circ}$ [Daniel et al., 1977; Maillet et al., 1983]. The most continuous feature of the DEZ is termed the North D'Entrecasteaux Ridge (NDR) and stretches the whole length from the continental New Caledonia 

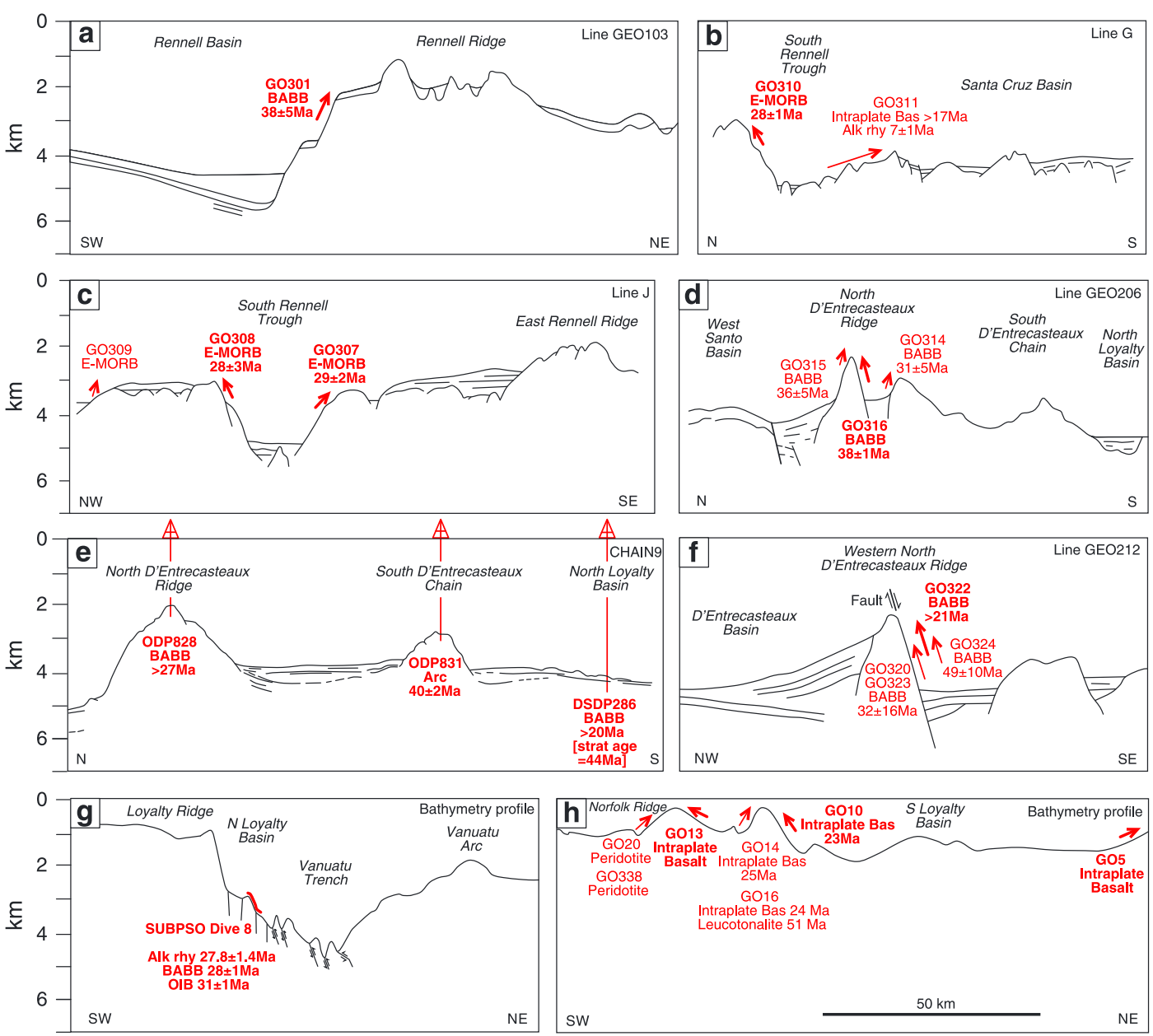

Figure 3. GEORSTOM, SUBPSO, DSDP, IODP, and sample positions located (bold type) and projected (plain type) onto shallow reflection seismic and bathymetric cross sections of Luyendyk et al. [1974], Daniel et al. [1978], Maillet et al. [1983], and Monzier [1993]. All panels drawn at same scale, vertical exaggeration is approximately 8 times. Vertical axis refers to water depth only; seismic profile numbers are given in top right hand corners (e.g., GEO103). (a) Rennell Basin and Ridge, (b) South Rennell Trough to Santa Cruz Basin, (c) South Rennell Trough flanks, (d) middle North D'Entrecasteaux Ridge, (e) western North D'Entrecasteaux Ridge to Loyalty Ridge, (f) eastern North D'Entrecasteaux Ridge to North Loyalty Basin, and (g) south end of North Loyalty Basin

Ridge to the Vanuatu Trench (Figures 2 and $3 d-3 f$ ). The NDR is considered to be a major oblique strikeslip fault zone analogous to the present day Hunter Fracture Zone connecting the Vanuatu arc with Fiji [Daniel et al., 1977, 1978]. It has also been regarded as part of a major regional oroclinal bend [Johnston, 2004]. Samples dredged along the length of the NDR have previously been interpreted to be of mid-ocean ridge basalt composition and glass rinds from four samples were dated by fission track methods as 36-56 Ma [Maillet et al., 1983]. ODP site 828 was drilled at the east end of the NDR and bottomed in a middle Eocene volcanic breccia unit [Shipboard Scientific Party, 1994a]. Coltorti et al. [1994] reported the chemistry of one suite of breccia clasts to be similar to mid-ocean ridge basalts and another suite to be similar to island arc tholeiites.

The name South D'Entrecasteaux Chain (SDC) has been used for a linear alignment of three to five seamounts including Bougainville Guyot and Sabine Bank (Figures 2, 3d-3f). The SDC is considered to be a prolongation of the Loyalty Ridge by many authors [e.g., Crawford et al., 2003] but there are few volcanoes between the NW trending Loyalty Ridge sensu stricto and the South D'Entrecasteaux Chain. We question this correlation and discuss its possible origins below. Bougainville Guyot has been sampled by diving [Collot et al., 1992] and also by drilling at ODP Site 831 [Baker et al., 1994; Shipboard Scientific Party, 1994b]. The rocks bottomed in low-K andesites and a K-Ar whole-rock age of $37 \pm 1 \mathrm{Ma}$ [Rex, 1994] was regarded as dating subduction-related volcanism. 
Collectively, the North D'Entrecasteaux Ridge and a genetically related South D'Entrecasteaux Chain-Loyalty Ridge have been regarded in many syntheses [e.g., Crawford et al., 2003; Schellart et al., 2006] as an obliquely convergent subduction zone and its volcanic arc.

\subsection{Loyalty Ridge and North Loyalty Basin}

The North Loyalty Basin is perhaps the best known of all the small basins in the study area (Figures 2, 3d, 3e, and 3g), but sampling within the basin is limited to Deep Sea Drilling Project (DSDP) site 286 plus some magnetic interpretations [Shipboard Scientific Party, 1975; Weissel et al., 1982; Sdrolias et al., 2003]. DSDP site 286 bottomed in basalt intruded by gabbro [Stoeser, 1975; Peate et al., 1997]. The age of basement must be older than the overlying middle to late Eocene sedimentary rocks. The source of the thick section of middle to late Eocene volcaniclastic and tuffaceous strata has been regarded as the South D'Entrecasteaux Chain and Loyalty Ridge. Lapouille [1978] has considered the South Fiji and North Loyalty basins to formerly be one basin.

\subsection{Norfolk Ridge}

The northern Norfolk Ridge is the submarine continuation of New Caledonia continental crust. As such, it is the shallowest major feature considered here (Figures 2 and 3h). Results of the ORSTOM dredging, including some major element rock analyses and whole-rock K-Ar and micropaleontological ages, were presented by Daniel et al. [1976] and Bitoun and Récy [1982]. Thus, the occurrence of serpentinite, basalt, and limestone that can be correlated with geological units in onland New Caledonia has been known for some time. Perhaps because it was published in the "grey literature," this information is not as well known and used as it should be.

\section{Methods}

Rocks from the GEORSTOM cruises were stored at ORSTOM (later Institut de Recherche pour le Développement) in Nouméa and reexamined and subsampled by Mortimer and Herzer in September 2008. Many of the samples had clearly been sawn and picked over; in some cases no rocks remained from certain dredges. To supplement the GEORSTOM rocks, core samples were also obtained from the drill holes DSDP 286 and 287 and ODP 829 and 831 . The selected samples were thin sectioned to assess their suitability for further analysis. Table 1 lists the complete sample set for this paper.

Whole-rock powders for chemical analysis were prepared by removing manganese and alteration rinds from samples, leaving clean, trimmed, $5 \mathrm{~mm}$ thick slices of the freshest possible material. In order to remove seawater-precipitated salts, these rock slices were soaked in de-ionized water for 7 days. Following this, they were dried and ground to powder in a tungsten carbide ring mill at GNS Science. Major elements and As, Ba, $\mathrm{Cr}, \mathrm{Cu}, \mathrm{Ga}, \mathrm{Ni}, \mathrm{Sc}, \mathrm{V}$, and $\mathrm{Zn}$ were determined by X-ray fluorescence methods on fused glass discs in a Philips PW 2400 machine in the University of Otago Geology Department. The fused discs were then mounted in epoxy, ground and polished. An additional 25 trace elements were measured by laser ablation inductively coupled plasma mass spectrometry (LA-ICP-MS) using facilities in the Otago Community Trust Centre for Trace Element Analysis at the University of Otago. Laser ablation was conducted with a pulsed NewWave $213 \mathrm{~nm}$ laser operated at $2-4 \mathrm{~J} / \mathrm{cm}^{2}$ fluence, at $10 \mathrm{~Hz}$ using a spot diameter of $100 \mu \mathrm{m}$ and a tracking rate of $5 \mu \mathrm{m} / \mathrm{s}$. Ablated material was carried by He gas from the sample cell, mixed with $\mathrm{Ar}$, and inlet into an Agilent 7500 ICP-MS. Each sample was measured 3-4 times and bracketed by analyses of standard glass National Institute of Standards and Technology (NIST) 610. Raw mass peak count rates were background-subtracted, corrected for mass bias drift, and converted to concentrations by reference to NIST 610 using an offline spreadsheet. Trace element concentrations were obtained by normalizing count rates for each element to those for $\mathrm{Si}$ in the sample and standard using known $\mathrm{SiO}_{2}$ and trace element concentrations in NIST 610 [Pearce et al., 1997].

Samples for radiometric dating were separated by standard sieving, heavy liquid, and magnetic separation techniques at GNS Science. U-Pb dating was done at Australian National University by the excimer laser ablation (ELA-ICP-MS) according to procedures described by Ballard et al. [2001].

For Ar-Ar dating, further magnetic separation, some acid washes in diluted $\mathrm{HCl}$ and/or $\mathrm{HF}$ of plagioclases, and final handpicking were done at the University of California Santa Barbara (UCSB). Splits of each sample ranging from 1 to $120 \mathrm{mg}$ were encapsulated in copper packets and loaded into a sealed quartz vial 
Table 1. Sample Locations by Feature From West to East ${ }^{\mathrm{a}}$

\begin{tabular}{|c|c|c|c|c|c|c|}
\hline Site & Depth $(m)$ & Latitude S (deg) & Longitude $\mathrm{E}$ (deg) & Site Description & Rock Types & GNS P\# \\
\hline \multicolumn{7}{|c|}{ Coral Sea Basin, Santa Cruz Basin, and South Rennell Trough } \\
\hline $287,17,1,140-151.5$ & $4870-4874$ & -13.9131 & 153.2655 & Coral Sea Basin & Basalt & 78802 \\
\hline GO301 & $2260-2970$ & -11.5419 & 159.4132 & Fault scarp between Rennell Basin and Ridge & Basalts & 78604,06 \\
\hline GO307 & $3360-3700$ & -13.9560 & 160.7132 & SE scarp of South Rennell Trough & Glass, basalt & 78611,12 \\
\hline GO308 & $3000-3400$ & -13.8236 & 160.5699 & NW scarp of South Rennell Trough & Basalt & 78613 \\
\hline GO309 & $2800-3260$ & -13.6402 & 160.4132 & approximately $30 \mathrm{~km} \mathrm{NW}$ of South Rennell Trough & Basalt & 78614 \\
\hline GO310 & $3100-3650$ & -12.0282 & 162.7266 & NW scarp of South Rennell Trough & Basalt & 78615 \\
\hline GO311 & $3840-4320$ & -12.4919 & 162.8366 & Santa Cruz Basin, E of South Rennell Trough & Rhyolite, basalt & 78616,17 \\
\hline \multicolumn{7}{|c|}{ D'Entrecasteaux Ridge } \\
\hline GO314 & $2800-3120$ & -15.5519 & 165.0499 & North D'Entrecasteaux Ridge, central part & Basalt & 78618 \\
\hline GO315 & $1800-2160$ & -15.3952 & 164.9866 & North D'Entrecasteaux Ridge, central part & Basalt & 78621 \\
\hline GO316 & $2200-2960$ & -15.4686 & 164.5732 & North D'Entrecasteaux Ridge, central part & Basalts & 78622,23 \\
\hline GO317 & $2600-3200$ & -15.5819 & 164.4399 & North D'Entrecasteaux Ridge, central part & Basalts & 78627,29 \\
\hline GO320 & $3640-4150$ & -15.9052 & 163.3882 & North D'Entrecasteaux Ridge, central part & Basalt & 78630 \\
\hline GO322 & $2500-3680$ & -16.2019 & 163.1282 & North D'Entrecasteaux Ridge, central part & Basalts & 78631,32 \\
\hline GO323 & $3250-4180$ & -15.8952 & 163.3899 & N D'Entrecasteaux Ridge, $1 \mathrm{~km}$ north of GO320 & Basalt & 78633 \\
\hline $\mathrm{GO} 324$ & $3020-3750$ & -16.7719 & 162.8432 & North D'Entrecasteaux Ridge, western part & Basalts & 78635,40 \\
\hline $828 \mathrm{~B}, 3, \mathrm{CC}, 0.0-7.5$ & $3192-3201$ & -15.2896 & 166.2825 & North D'Entrecasteaux Ridge, western part & Basalt breccia & 78811 \\
\hline $831 B, 71,3,0-9$ & $1812-1822$ & -16.0112 & 166.6725 & Bougainville Guyot (South D'Entrecasteaux Chain) & Andesite breccia & 78805 \\
\hline \multicolumn{7}{|l|}{ North Loyalty Basin } \\
\hline $286,36,1,22-36$ & $5114-5123$ & -16.5339 & 166.3695 & North Loyalty Basin, northern end & Basalt, unit 3 & 78800 \\
\hline SUBPSO 801A & $4555-4607$ & -21.7401 & 169.1331 & Loyalty Basin, southern end & Rhyolite & 78659 \\
\hline SUBPSO 804 & 4200 & -21.7448 & 169.1265 & Loyalty Basin, southern end & Basalt & 78662 \\
\hline SUBPSO 805A & 4185 & -21.7454 & 169.1256 & Loyalty Basin, southern end & Basalt & 78663 \\
\hline \multicolumn{7}{|c|}{ Norfolk and Loyalty Ridges } \\
\hline GO5 & 1060 & -22.0936 & 168.4828 & Loyalty Ridge & Volc breccia & 78586 \\
\hline G010 & $1210-1380$ & -23.2952 & 168.2948 & North Norfolk Ridge & Trachyandesite & 78588 \\
\hline G013 & $1400-1620$ & -23.0019 & 168.5498 & North Norfolk Ridge & Basalt & 78589 \\
\hline GO14 & $1200-1480$ & -23.5303 & 168.8398 & North Norfolk Ridge & Trachyandesite & 78590 \\
\hline GO16 & $1210-1250$ & -23.6502 & 168.8368 & North Norfolk Ridge & L'tonalite, T'basalt & 78594,95 \\
\hline GO20 & $1265-1275$ & -24.0786 & 168.0081 & North Norfolk Ridge, massif on east side & Pyroxenite & 78602 \\
\hline GO338 & 1600 & -24.0719 & 168.6481 & North Norfolk Ridge & Serpentinite & 78643 \\
\hline
\end{tabular}

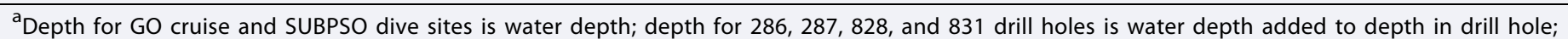
L'tonalite = leucotonalite and $T^{\prime}$ basalt $=$ trachybasalt.

interspersed with packaged flux monitors. Vials were irradiated in a cadmium-lined tube at the TRIGA (Training, Research, Isotopes, General Atomics) reactor at Oregon State University in several different irradiations for durations of 8 to $20 \mathrm{~h}$ depending on the estimated ages of the samples. All samples were analyzed in the ${ }^{40} \mathrm{Ar} /{ }^{39} \mathrm{Ar}$ geochronology laboratory at UCSB by heating in a Staudacher-type resistance furnace with isotopic analysis on a MAP 216 mass spectrometer using the general procedures and system described by Gans [1997]. The flux monitor used for all irradiations was Taylor Creek Rhyolite with an assigned age of $27.92 \mathrm{Ma}$ [Dalrymple and Duffield, 1988]. For comparison, we obtain an age of $27.60 \mathrm{Ma}$ on Fish Canyon Tuff sanidine, another widely used standard. All errors given for our estimated (preferred) ages as reported throughout the text are $\pm 2 \sigma$ (95\% confidence). For dating of the very low-K/Ca plagioclase and groundmass materials, particular attention was paid to precisely assessing the Ca-derived $\left({ }^{36} \mathrm{Ar} /{ }^{37} \mathrm{Ar}\right.$ and $\left.{ }^{39} \mathrm{Ar} /{ }^{37} \mathrm{Ar}\right)$ reactor constants, mass discrimination, and tailing corrections that are normally not a large factor in Ar-Ar dating but which become significant for samples with extremely low-K/Ca ratios $(<0.01)$. Analyses ranged from total fusion experiments to 15 step incremental heating experiments. In some cases, replicate splits and/or multiple minerals were analyzed from the same unit to check for internal consistency and to improve precision. Ages were reduced and spectra generated using Brad Hacker's Eyesorechron program.

All analyzed samples were given GNS Science "P numbers" and catalogued in GNS Science's National Petrology Reference Collection. Sample and analytical data are lodged in the PETLAB database (http://pet.gns.cri.nz/) under Collector $=$ ORSTOM. 

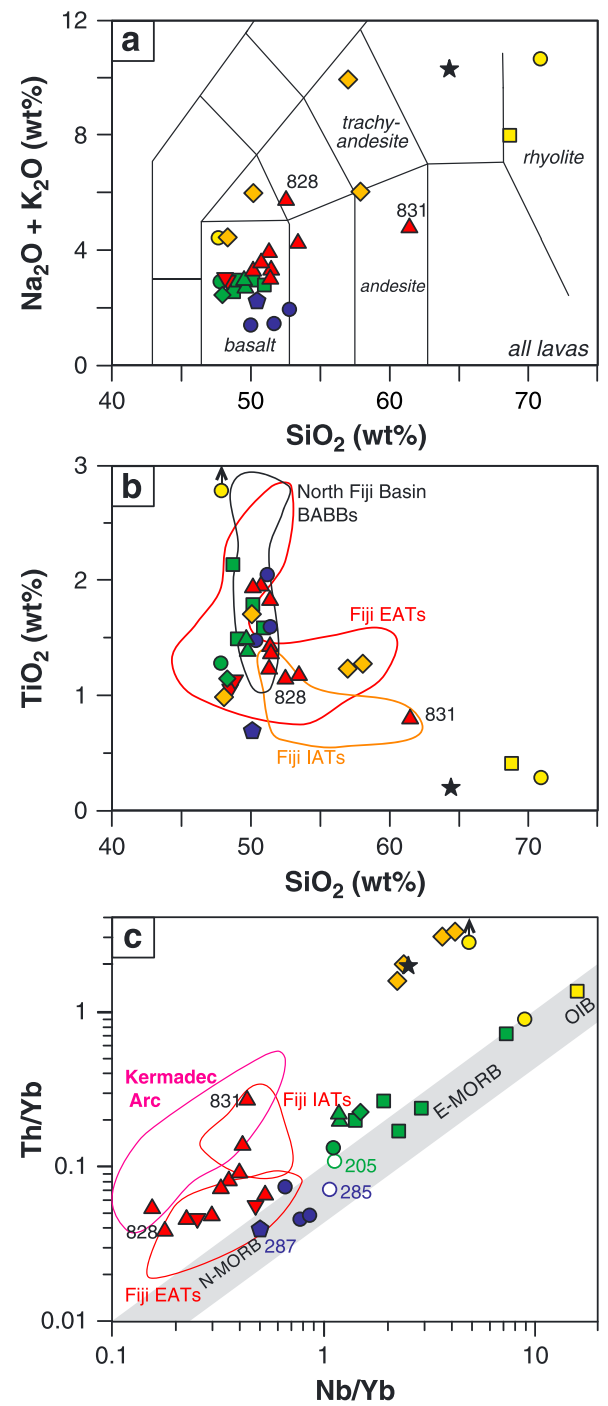

Figure 4. Selected binary geochemical diagrams (major elements have been normalized to $100 \mathrm{wt} \%$ on a loss on ignition-free basis) (a) $\mathrm{SiO}_{2}$ versus total alkalies after Le Bas et al. [1986], (b) $\mathrm{SiO}_{2}$ versus $\mathrm{TiO}_{2}$ North Fiji Basin and Fiji fields from Price et al. [1990] and Todd et al. [2012], and (c) $\mathrm{Nb} / \mathrm{Yb}$ versus $\mathrm{Th} / \mathrm{Yb}$ after Pearce [2008], Fiji and Kermadec fields from Todd et al. [2012]. DER = D'Entrecasteaux Ridge, DEC = D'Entrecasteaux Chain, $\mathrm{MORB}=$ mid-ocean ridge basalt, $\mathrm{BABB}=$ back-arc basin basalt, $\mathrm{IAT}=$ island arc tholeiite, EAT = early arc tholeiite. Symbology as in Figure 2.

elements have been consistently enriched by seafloor alteration processes. Whole-rock concentrations of $\mathrm{Cs}, \mathrm{U}$, and $\mathrm{Pb}$ are up to 10 times expected concentrations in these rocks, and $\mathrm{Rb}$ and $\mathrm{K}$ have $2-5$ times expected concentrations. Sr and $\mathrm{P}$ concentrations are variable, both above and below expected on normalized multielement diagrams. Because of this, the elements $\mathrm{Cs}, \mathrm{Rb}, \mathrm{U}, \mathrm{K}, \mathrm{Pb}, \mathrm{Sr}$, and $\mathrm{P}$ have been excluded from our multielement normalized diagrams in the main paper. We confine our interpretation to establishing broad geochemical characteristics and do not do any petrogenetic modeling.

We have plotted our data on multielement diagrams in which elements are normalized to those in normal midocean ridge basalts (N-MORBs) (Figure 5). In Figure 5, following Thompson [1982] and Pearce [2008], we have also double-normalized to $\mathrm{Lu}=1$. This partially corrects for effects of crystal fractionation and calcite and phosphate dilution and enables more ready comparison of samples' compositions as they relate to source regions. The samples fall into six broad categories based on rock type, petrography, and geochemical composition. 


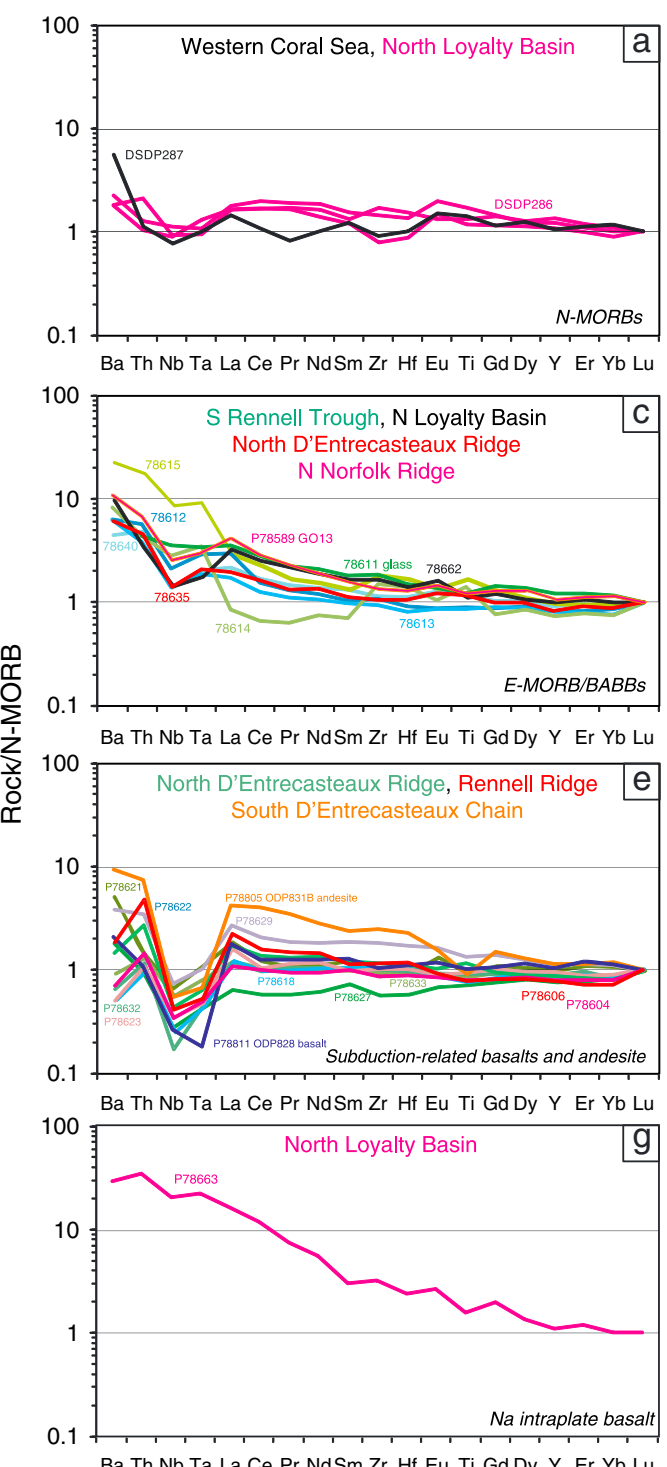

Ba Th Nb Ta La Ce Pr NdSm Zr Hf Eu Ti Gd Dy Y Er Yb Lu

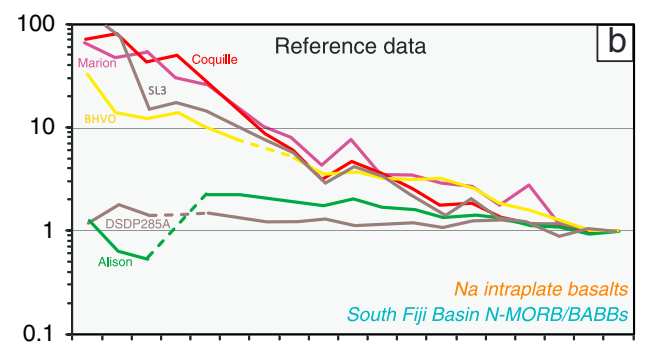

Ba Th Nb Ta La Ce Pr NdSm Zr Hf Eu Ti Gd Dy Y Er Yb Lu

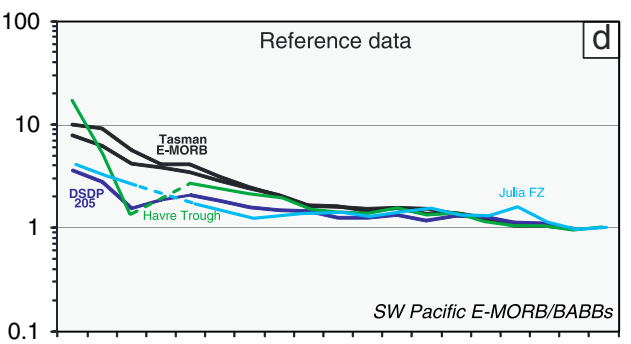

Ba Th Nb Ta La Ce Pr NdSm Zr Hf Eu Ti Gd Dy Y Er Yb Lu

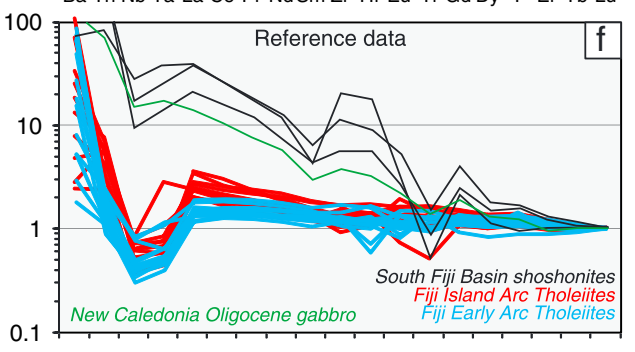

Ba Th Nb Ta La Ce Pr NdSm Zr Hf Eu Ti Gd Dy Y Er Yb Lu

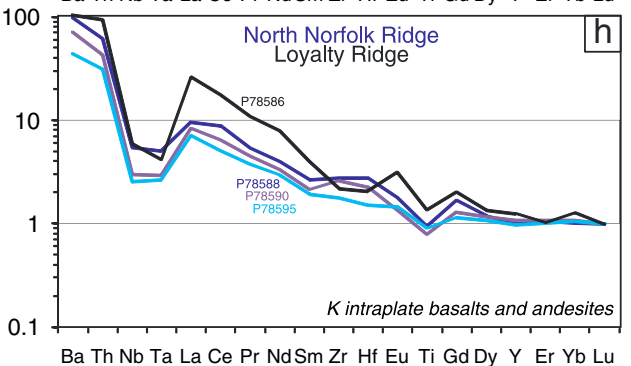

Figure 5. Multielement normalized diagrams of Coral Sea region basalts and andesites (i.e., siliceous rocks excluded) grouped by interpreted composition. (a) N-MORBs new data, (b) N-MORB and sodic intraplate reference data [Mortimer et al., 2007], (c) E-MORBs with back-arc basin influence new data, (d) SW Pacific E-MORB reference data, (e) primitive subductionrelated basalts new data, (f) Fiji Early Arc Tholeiites, Fiji Island Arc Tholeiite, and South Fiji Basin shoshonite reference data, (g) sodic intraplate basalt new data, and (h) potassic intraplate basalts new data. N-MORB normalizing factors after Sun and McDonough [1989]. Reference data from Cluzel et al. [2005], Mortimer et al. [2007, 2012], and Todd et al. [2012]. $\mathrm{MORB}=$ mid-ocean ridge basalt, $\mathrm{BABB}=$ back-arc basin basalt.

\subsection{N-MORB Lavas}

$\mathrm{MgO}$ in these lavas is 6-8 wt \% and all but one have $\mathrm{Cr}>140 \mathrm{ppm}$. DSDP 286 analyses all have $\mathrm{TiO}_{2}>1 \mathrm{wt} \%$ but DSDP 287 is $<1 \mathrm{wt} \%$. High-quality trace element analyses of three samples from DSDP 286 in the North Loyalty Basin were made by Peate et al. [1997] and are plotted in Figures 4 and 5a; no new analyses from DSDP 286 were made for this study. The flat multielement patterns in Figure 5 a indicate N-MORB but perhaps with slightly more prominent Nb troughs than typical Pacific N-MORB.

Our new analysis of basalt from DSDP 287 in the Coral Sea Basin adds to the original analyses of Stoeser [1975]. The otherwise flat multielement normalized pattern demonstrates the presence of N-MORB at this site near the Queensland Plateau continent-ocean boundary, although the lava is generally depleted in incompatible trace element concentrations (Table S1). Shipboard Scientific Party [1975] dated the sediments 
overlying the DSDP 287 basalt as early Eocene (49-56 Ma) and Sdrolias et al. [2003] placed anomaly 27o (circa $62 \mathrm{Ma}$ ) near the site. This is the only sample site of igneous basement so far sampled from the entire Coral Sea Basin and contrasts with Tasman Sea E-MORBs of 60-68 Ma age [Mortimer et al., 2012].

\subsection{E-MORB Back-Arc Basin Lavas}

Lavas dredged from all five sites in and near the South Rennell Trough show the element ratios of E-MORBs from back-arc basins. So do isolated samplings of one of the lavas at the SUBPSO dive site in the southernmost North Loyalty Basin, one lava at dredge GO324 in the western North D'Entrecasteaux Ridge and one lava from dredge GO13 on the North Norfolk Ridge. These rocks all have slightly higher total alkali contents than the $\mathrm{N}-\mathrm{MORBs}$ (Figure 4a), $\mathrm{TiO}_{2}>1 \mathrm{wt} \%$ (Figure 4b), $\mathrm{MgO} 5-8 \mathrm{wt} \%$, and $\mathrm{Cr}>150 \mathrm{ppm}$. They have similar high field strength and middle and heavy rare earth element (REE) concentrations to N-MORB but have elevated large-ion lithophile element and light REE that give negative slopes to the lines to the left of Sm in Figure $5 \mathrm{~b}$. On the $\mathrm{Nb} / \mathrm{Yb}$ versus $\mathrm{Th} / \mathrm{Yb}$ diagram (Figure $4 \mathrm{c}$ ) the E-MORBs plot along or close to the mantle array (grey band) but with higher values than N-MORBs. Most lavas show slight Nb and Ta depletion relative to Th and La (Figure 5b), a common feature of SW Pacific back-arc basin lavas. Although we have no isotope data for our samples, these might possibly correspond to what is sometimes referred to as Indian Mantle MORB in a SW Pacific Ocean context, rather than the N-MORBs which are Pacific Mantle MORB-like [e.g., Hergt and Woodhead, 2007].

\subsection{Subduction-Related Basalts and Andesites}

A third group of basalts, basaltic andesites, and andesites from the North D'Entrecasteaux Ridge, South D'Entrecasteaux Chain, and the Rennell Ridge have some of the geochemical features of subduction-related igneous suites and some of the characteristics of N-MORBs. On average, basalts of this group have slightly higher total alkalies than the MORBs (Figure 4a). MgO and $\mathrm{Cr}$ concentrations are typically 3-6 wt \% and 50150 ppm; i.e., many are more fractionated than the MORBs. On the $\mathrm{Nb} / \mathrm{Yb}$ versus $\mathrm{Th} / \mathrm{Yb}$ diagram the analyses plot above the N-MORB mantle array (Figure $4 \mathrm{~b}$ ) indicative of a slab-related petrogenesis. On multielement normalized diagrams (Figure $5 \mathrm{e}$ ) they have prominent $\mathrm{Nb}$ and Ta troughs, much more pronounced than the E-MORB lavas described above.

It is noteworthy that this group of lavas has $\mathrm{TiO}_{2}$ contents between 1 and $2 \mathrm{wt} \%$. This is unusually high for island arc tholeiites. Compilations by many authors have noted that in individual island arc and back-arc systems, the cutoff in $\mathrm{TiO}_{2}$ between island arc tholeiites and back-arc basins is $0.8-1.3 \mathrm{wt} \%$. However, Todd et al. [2012] have recently shown that early arc lavas from Fiji and Tonga have the depleted $\mathrm{Nb}$ and Ta of arc lavas but with $\mathrm{TiO}_{2}$ ranging nearly as high as $3 \mathrm{wt} \%$ (Figures $4 \mathrm{~b}$ and $5 \mathrm{f}$ ). In all respects, the geochemistry of the lavas from the Rennell Ridge and D'Entrecasteaux Ridge match very well with the Fiji Early Arc Tholeiites, a point that is discussed later in the paper.

\subsection{Sodic Alkaline, Intraplate Basalt, and Rhyolites}

A rhyolite from the G0311 dredge site in the Santa Cruz Basin and a basalt and a rhyolite (comendite) from the SUBPSO dive site at the southernmost end of the North Loyalty Basin are placed in this grouping. All three samples are silica undersaturated with higher total alkalies at similar $\mathrm{SiO}_{2}$ concentrations than other suites (Figure 4a). The samples have ocean island basalt-like $\mathrm{Nb} / \mathrm{Yb}$ ratios (Figure $4 \mathrm{c}$ ). The basalt has the distinctive straight and negative slopes on the N-MORB normalized multielement diagram (Figures $5 \mathrm{~b}$ and $5 \mathrm{~g}$ ). These are further examples of low-volume eruptions of sodic intraplate volcanic rocks that occur scattered across the continent of Zealandia and the surrounding Cretaceous and Cenozoic oceanic crust.

\subsection{Potassic Alkaline, Intraplate Basalts and Andesites}

A basalt, a trachybasalt, and two trachyandesites from four dredge sites spanning the North Norfolk Ridge-Loyalty Ridge area have relatively high total alkalies (Figure 4a). This is caused by higher $\mathrm{K}_{2} \mathrm{O}$ and on an $\mathrm{SiO}_{2}$ versus $\mathrm{K}_{2} \mathrm{O}$ diagram (not shown) three rocks plot along the medium-high $\mathrm{K}$ series boundary, and one (P78615 from GO10) is shoshonitic. Although submarine rocks are susceptible to addition of potassium, we believe that the high potassium is primary, not secondary as these four rocks have the features of high-K alkaline igneous rocks based on other elements (e.g., La on Figure $5 \mathrm{~h}$, high $\mathrm{Th} / \mathrm{Nb}$ on Figure $4 \mathrm{c}$ ). 
The four rocks have much in common with early Miocene arc-rift shoshonites from seamounts in the South Fiji Basin reported by Mortimer et al. [2007], notably an E-MORB to ocean island basalt-like source as revealed by its $\mathrm{Nb} / \mathrm{Yb}$ ratio (Figure $4 \mathrm{c}$ ) and very high $\mathrm{N}-\mathrm{MORB}$ normalized $\mathrm{Ba}$ and Th and low N-MORB normalized $\mathrm{Nb}, \mathrm{Ta}$, and Ti relative to other elements (Figures $5 \mathrm{f}$ and $5 \mathrm{~h}$ ).

\subsection{Altered Leucotonalite}

A hard, pale grey granitoid from dredge site G016 on the North Norfolk Ridge dredge site was sampled and analyzed (P78594). The rock was not in contact with any other rock type but occurs in the same dredge as a trachybasalt. In thin section the rock has a weakly gneissic and strongly cataclastic texture with relict primary quartz, (albitized) plagioclase and traces of K-feldspar. Secondary minerals are abundant and include quartz, actinolite (presumably after primary hornblende), sericite, prehnite, and epidote. The latter two occur in cross-cutting veinlets. Because of the strong textural and mineralogical alteration, it is difficult to confidently assign a primary igneous rock name to this sample. However, the moderate quartz, low K-feldspar, low amphibole, moderate $\mathrm{SiO}_{2}$, and high $\mathrm{Na}_{2} \mathrm{O}$ contents (Figure 4a) collectively indicate that a leucotonalite rock name probably is most appropriate for the protolith.

\section{Ar-Ar Dating}

We report the results of 48 individual Ar-Ar age determinations on handpicked groundmass, plagioclase, and amphibole separates from 24 samples. Analytical results and our preferred eruptive ages are summarized in Table 2, and a selection of step-heating spectra are given in Figure 6. Full tables of analyses and step-heating spectrum, isochron, and K/Ca plots for all samples are given in Table S2. For nine samples both plagioclase and groundmass fraction were dated. For 11 samples different amounts of material from the same sample were irradiated in two separate batches (SB61 and SB63) to cross check for correction factors.

Most samples produced interpretable ages. Plagioclase often yielded relatively flat age spectra with concordant plateau and inverse isochron ages for large fractions of the gas released. Groundmass concentrates from mafic lavas invariably yielded results that were somewhat more complex. Individual age spectra range from "hump" to " $U$ " to "L shaped." The shapes of these spectra and their deviations from idealized flat plateaux are interpretable in terms of the combined effects of variable contributions of reactor-induced recoil, low-temperature argon loss, mixed phases due to hydrothermal alteration, and a nonatmospheric "trapped" component (i.e., excess argon). In particular, argon loss due to hydration and clay alteration of interstitial groundmass glass tends to yield young apparent ages, especially in the lowest temperature steps. Excess argon tends to be trapped in the early crystallized phenocryst phases (e.g., olivine and plagioclase) and is generally most evident in the highest temperature steps associated with the lowest apparent $\mathrm{K} / \mathrm{Ca}$ ratios. In general, the flattest and most reliable parts of individual spectra are associated with the gas released at intermediate to high temperatures (approximately 800 to $1050^{\circ} \mathrm{C}$ ). Though many of the mafic groundmass separates did not yield strict plateau ages (commonly defined as concordant ages on contiguous steps representing greater than $50 \%$ of the total gas), we believe that they still can provide an accurate assessment of the eruptive age of the volcanic rocks in question. Empirical studies by Gans and Bohrson [1998] on mafic volcanic samples whose ages are closely bracketed by sanidine-bearing tuffs have shown that the mean age given by the reasonably flat central to high-temperature part of the spectrum generally provides a reliable estimate of the age, even if it does constitute less than $50 \%$ of the gas released or does not strictly define a statistical plateau. In cases where the individual steps in such a segment do not lie within $2 \sigma$ analytical uncertainty of each other, we assign an uncertainty corresponding to approximately four standard deviations of the selected ages - a somewhat arbitrary assessment but one that has proven appropriate and conservative in other studies. Based on argon degassing measurements, our samples fall into three categories.

\subsection{Relatively High Quality Samples—Statistical Plateaux}

The best analyses are those in which the signal size relative to blanks is good, the radiogenic yields are moderate to high, and the majority of the degassing steps form a relatively straightforward and flat age spectrum (Figures 6a-6d, listed as high quality in Table 2). K/Ca ratios are reasonably high for groundmass but can be 0.005 for plagioclase. Many samples have groundmass ages that either overlap within error of or are slightly younger than the plagioclase ages. In these cases we have a fair amount of confidence that the 


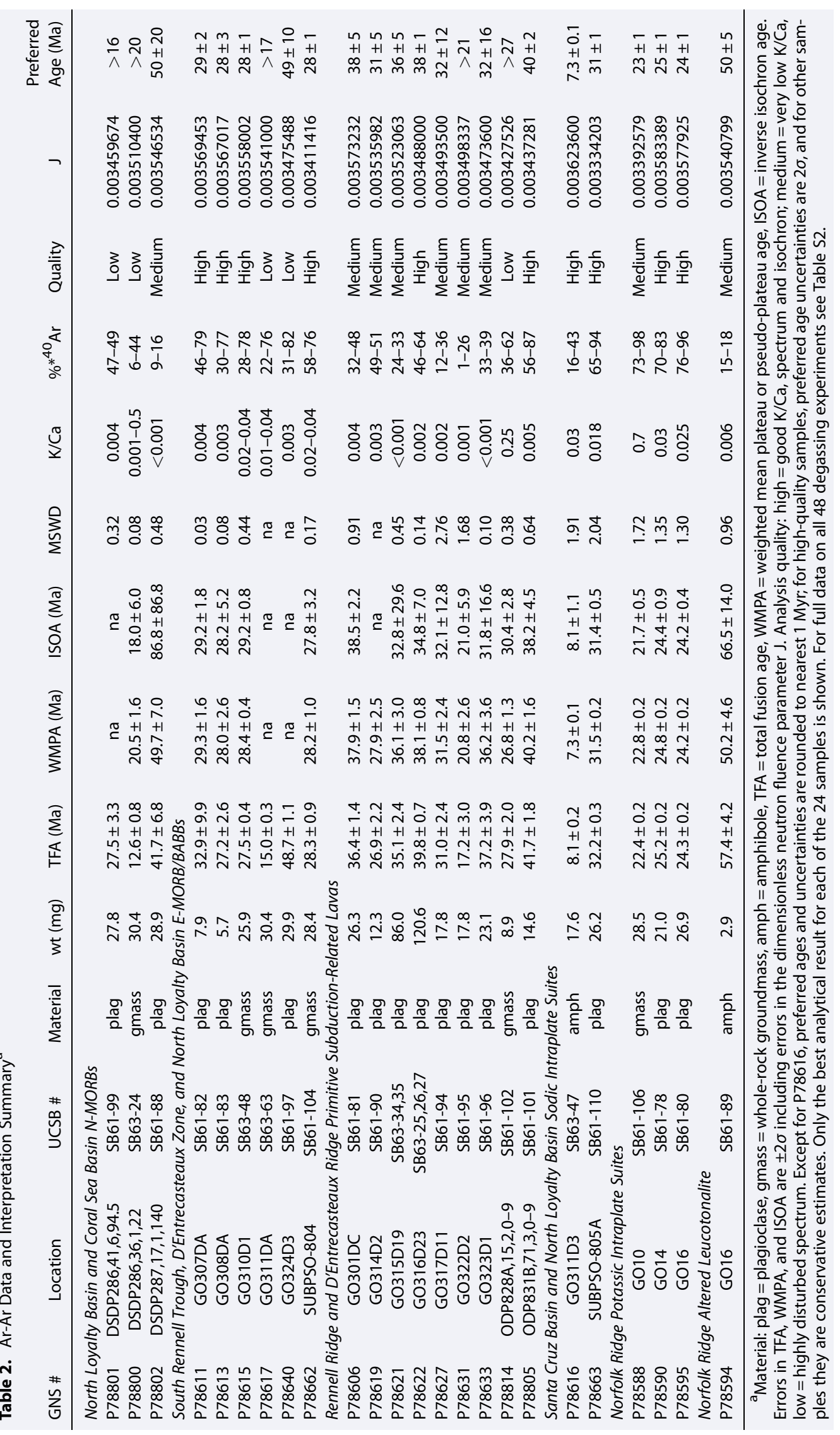



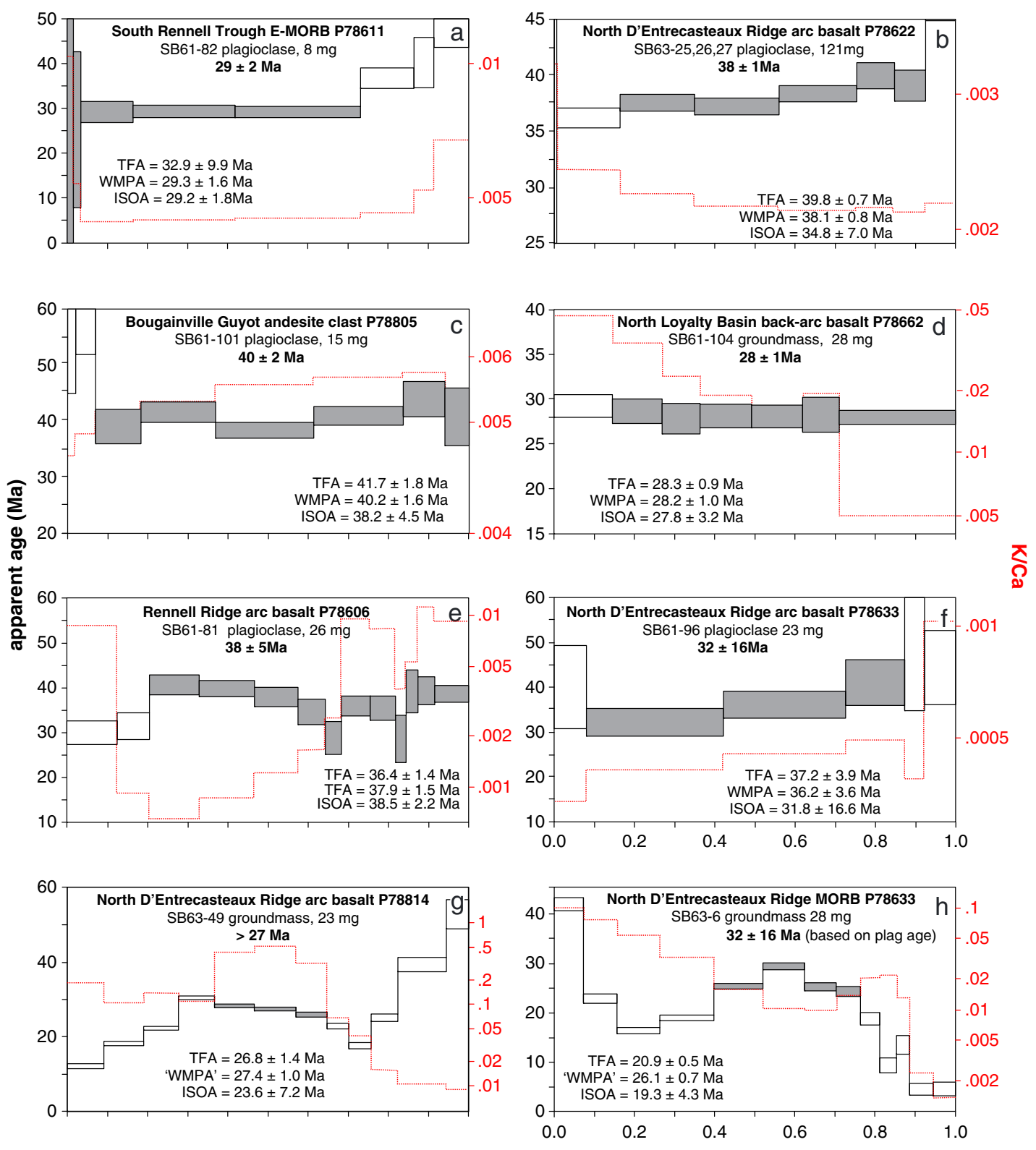

cumulative ${ }^{39} \mathrm{Ar}$

Figure 6. Ar-Ar spectra (a-d) representative of relatively high quality data, (e and f) representative of medium-quality data, and ( $g$ and $h$ ) representative of lowquality data. Red lines are K/Ca values. Grey parts of age spectra were used for age calculations. Height of bars is $\pm 1 \sigma$ but quoted ages are $\pm 2 \sigma$.

eruptive age of the lava conservatively lies within the calculated age of the plagioclase (which usually has a larger age error than the groundmass).

P78611 (South Rennell Trough) is a typical example of a well-behaved, relatively high quality sample with low-K/Ca plagioclase (Figure 6a). Apparent K/Ca ratios were low but not as low as some samples, and there is a statistical plateau for $73 \%$ of the gas released. The plagioclase gave a calculated age of $29.3 \pm 1.6 \mathrm{Ma}$. Other examples of relatively high quality samples are the South Rennell Trough samples P78613 and P78615 (not shown). Plagioclase spectra for these samples are similar to P78611, and in addition, the plagioclase and groundmass ages lie within error of each other and are interpreted as giving eruptive ages of $28 \pm 3$ and $28 \pm 1 \mathrm{Ma}$, respectively.

A large, $121 \mathrm{mg}$ sample of plagioclase from North D'Entrecasteaux Ridge basalt P78622 was run to give a high-precision determination (Figure 6b). Although the K/Ca ratios are half that of P78611, the sample yielded 
a flat spectrum and a good plateau for $76 \%$ of the gas released. The biggest uncertainty for this sample is in the Ca correction factor, but with our close monitoring, we consider it unlikely that these would significantly change the accuracy of the $38 \pm 1 \mathrm{Ma}$ age. Plagioclase from P78805, a Bougainville Guyot andesite clast has small radiogenic argon signals but a reasonably flat spectrum (Figure $6 \mathrm{c}$ ). Its $\mathrm{K} / \mathrm{Ca}$ is the highest of all plagioclase separates in our sample set. The total fusion, weighted mean plateau, and isochron ages are all in agreement; our preferred age for this sample is $40 \pm 2 \mathrm{Ma}$.

Another example of a relatively high quality age determination, this time from a groundmass separate, is P78662 from the North Loyalty Basin (Figure 6d). This separate gave large radiogenic argon signals, high-K/Ca ratios, a flat spectrum, and agreement between calculated plateau and isochron ages. Our single igneous amphibole age $(7.3 \pm 0.1 \mathrm{Ma})$ for trachyte P78616 is also relatively high quality, with an excellent plateau for $77 \%$ of the gas released (not shown) and $\mathrm{K} / \mathrm{Ca}$ ratios that are appropriate for a fresh igneous amphibole.

\subsection{Medium-Quality Samples-Low $\mathrm{K} / \mathrm{Ca}$}

In some samples, the dated plagioclase and/or groundmass is perfectly fresh and unaltered but has very little potassium especially with respect to calcium (Figures $6 e$ and $6 f$, labeled medium quality in Table 2). This means that it is extremely difficult to get a reliable age because of the vulnerability of the age calculation to a number of correction factors, e.g., blanks, tailing (especially of Ca-derived ${ }^{37} \mathrm{Ar}$ on to ${ }^{36} \mathrm{Ar}$ ), mass discrimination, and from uncertainties in the precise amount of Ca-derived ${ }^{36} \mathrm{Ar}$ and ${ }^{39} \mathrm{Ar}$. Even very small uncertainties in these correction factors can propagate into large uncertainties in the calculated ages. To address these issues, we (1) irradiated larger quantities of material from the same separate in batch SB63 than batch SB61 in order to boost signal-to-noise ratio and (2) adjusted waiting time between irradiation and measurement to cross check our correction factors. In spite of these measures, some plagioclase samples still gave imprecise results. For our "preferred" ages we have arbitrarily adjusted the calculated $2 \sigma$ analytical precision to less precise values that we consider more appropriate for each sample.

Examples of very low precision plagioclase Ar-Ar ages include P78606, a basalt from the Rennell Basin. This has a bouncy spectrum (Figure 6e), and its apparent ages get younger as K/Ca climbs from an ultralow 0.001 up to a reasonable 0.01 . An imprecise age of $38 \pm 5 \mathrm{Ma}$ is based on the isochron age. In other samples (e.g., P78633, Figure 6f), the K/Ca ratios are typically less than 0.001 such that even when large (100 to $150 \mathrm{mg}$ ) samples are run, the majority of the mass 39 signals that are measured are actually calcium derived rather than produced from potassium. Although the spectrum of Figure $6 \mathrm{f}$ is arguably better behaved than in Figure $6 \mathrm{e}$, the signals are much smaller and errors on individual age steps much larger. This and other samples in our data set such as P78627 from North D'Entrecasteaux Ridge and P78802 from the western Coral Sea have such large errors as to be of little practical use; they represent the limits of Ar-Ar dating as applied to low-potassium, high-calcium materials.

\subsection{Low-Quality Samples-Disturbed Spectra}

In other cases, the dated materials yield very disturbed plagioclase and/or groundmass spectra with highly variable $\mathrm{K} / \mathrm{Ca}$ ratios (Figures $6 \mathrm{~g}$ and $6 \mathrm{~h}$, categorized low quality in Table 2 ). Possibly, this is due to hydrothermal alteration or incorporated excess argon, despite the plagioclase and groundmass appearing fresh and unaltered. Plagioclase "ages" are typically quite different and much older than groundmass ages from the same sample. Our preferred ages are not statistically meaningful, and the quoted errors are our qualitative estimates. Sometimes, quoted ages can only be interpreted as minima or maxima.

Groundmass material from P78814, a North D'Entrecasteaux Ridge basalt clast, has a disturbed spectrum that climbs, falls, and climbs again (Figure $6 \mathrm{~g}$ ). The sample has probably suffered argon loss as well as reactor recoil. The age of the top of the hump is probably a minimum age for the eruption of the basalt. Other samples that we believe that only give minimum ages include P78800 and 78801 from DSDP286, as well as P78631 from North D'Entrecasteaux Ridge and P78617 from the Santa Cruz Basin. Groundmass from North D'Entrecasteaux Ridge basalt P78633 gives a complex gas release spectrum with only the first age step approximating the plagioclase ages (compare Figure $6 \mathrm{~h}$ with Figure $6 \mathrm{f}$ ). The hump-shaped spectrum is suggestive of argon loss as well as reactor recoil and is of limited use in giving primary ages. Other samples to show such behavior are P78640 from the North D'Entrecasteaux Ridge and P78801 a basalt from DSDP 286. 

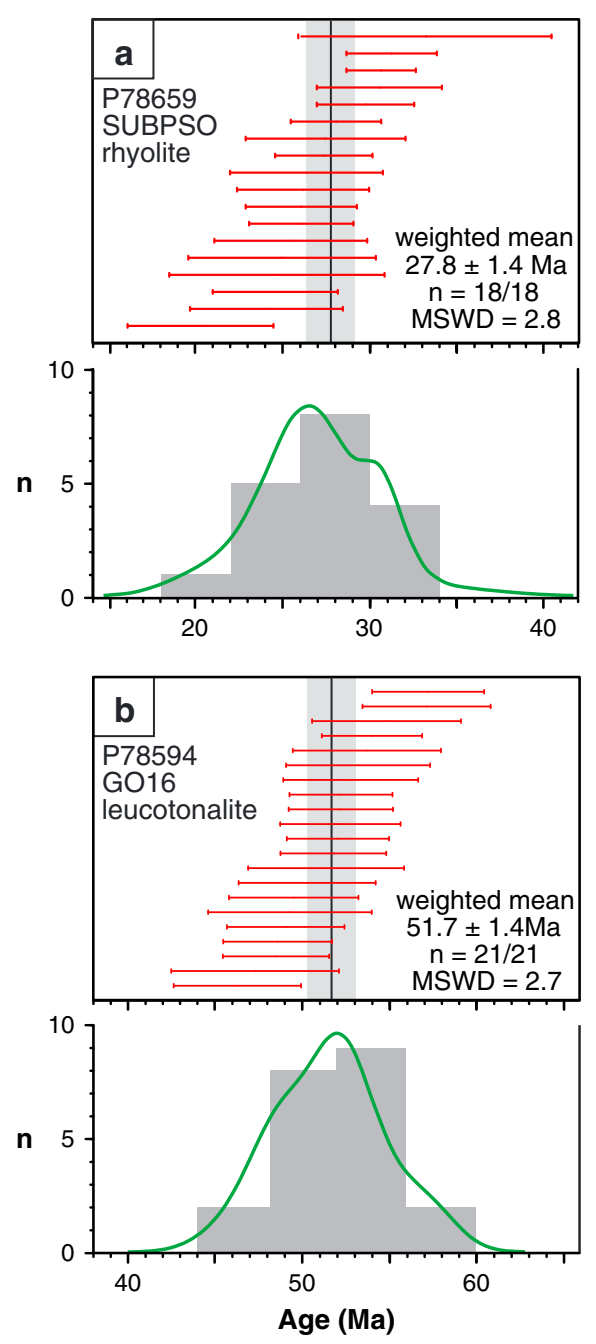

Figure 7. U-Pb zircon histograms and cumulative probability plots for (a) North Loyalty Basin alkali rhyolite and (b) Norfolk Ridge leucotonalite.

\section{U-Pb Dating}

Zircon was separated from two siliceous igneous samples, alkali rhyolite P78659 from the SUBPSO 8 dive site and from P78594, the altered leucotonalite from the Norfolk Ridge. Monzier [1993] previously reported a K-Ar age (presumably whole rock) of $32 \pm 2 \mathrm{Ma}$ for the SUBPSO rhyolite.

In both samples, the zircons appeared to belong to single morphological populations, and cathodoluminescence revealed no complicated zoning. Eighteen zircons were analyzed for P78659 and 21 for P78594. The results of $\mathrm{U}-\mathrm{Pb}$ dating are summarized in Figure 7, and full data given in Table S3. For both samples there is a hint that multiple age populations might be present but these cannot be satisfactorily resolved with the number of grains analyzed. The geology of the region is so poorly known that we do not yet have a geological basis to explore the detailed roles of antecrysts, assimilation, and/or Pb loss due to multiple thermal events. For the purposes of this paper, we include all dated zircons in each age calculation and report provisional weighted mean ages and $2 \sigma$ errors of $27.8 \pm 1.4 \mathrm{Ma}$ for the rhyolite and $51.7 \pm 1.4 \mathrm{Ma}$ for the leucotonalite.

\section{Interpretation}

Having presented and provisionally interpreted the data in terms of thematic igneous suites and geochronological quality, we further interpret the results in terms of geographic area (Figures 8 and 9).

\subsection{North Loyalty Basin}

Weissel et al. [1982] interpreted anomalies 18 to 23 younging from northwest to southeast in the North Loyalty Basin. Sdrolias et al. [2003] repicked these same anomalies as 160 to 20o (35-46 Ma). These latter picks (Figures 2, 8, and 9a) better fitted the stratigraphically constrained age of DSDP 286 at

circa $44 \mathrm{Ma}$ and suggested a half-spreading rate of $33 \mathrm{~mm} / \mathrm{a}$ in a NW-SE direction. The oldest and youngest magnetic anomalies differed in strike by $15^{\circ}$.

Our SUBPSO 8 dive site provides a very useful and important sampling of the southern part of the North Loyalty Basin crust. The $28 \pm 1$ Ma back-arc basin basalt, $31 \pm 1$ Ma sodic alkali basalt, and $28 \pm 2$ Ma sodic alkali rhyolite collectively date formation of new back-arc basin crust and magmatism related to the rift edge of the Loyalty Ridge-Loyalty Basin margin. The latter can be understood in terms of a fault-fault-ridge triple junction migrating southeast along the continent-ocean boundary. From the broad agreement in the ages of the petrologically different rocks we infer that the spreading ridge passed the location of the dive site at circa $28 \mathrm{Ma}$, accreting back-arc basin crust and inducing intraplate volcanism.

The SUBPSO dive site is some $350 \mathrm{~km}$ southeast of Sdrolias et al.'s [2003] last well-defined magnetic anomaly. Assuming the same direction of North Loyalty Basin spreading, our $28 \mathrm{Ma}$ age for the BABB accords with continuation of this spreading system at a slightly faster half-spreading rate to the SUBPSO dive site 8 . Thus, the recognized age range and rates of spreading in the North Loyalty Basin should now be modified from 35-46 Ma at $33 \mathrm{~mm} / \mathrm{a}$ [Sdrolias et al., 2003] to 28-46 Ma at $43 \mathrm{~mm} / \mathrm{a}$ (Figures 8 and 9a). Herzer et al. [2011] interpreted chron 9n (28 Ma) to be present in the northeastern South Fiji Basin (Figure 9a, bottom right corner). The existence of $28 \mathrm{Ma}$ back-arc basin crust at this location and at the SUBPSO dive site means that the Loyalty and South Fiji Basin crust were not formed on the same spreading system. A ridge jump and/or triple junction configuration (now subducted beneath the Vanuatu Arc) between them are needed to explain their occurrences. 


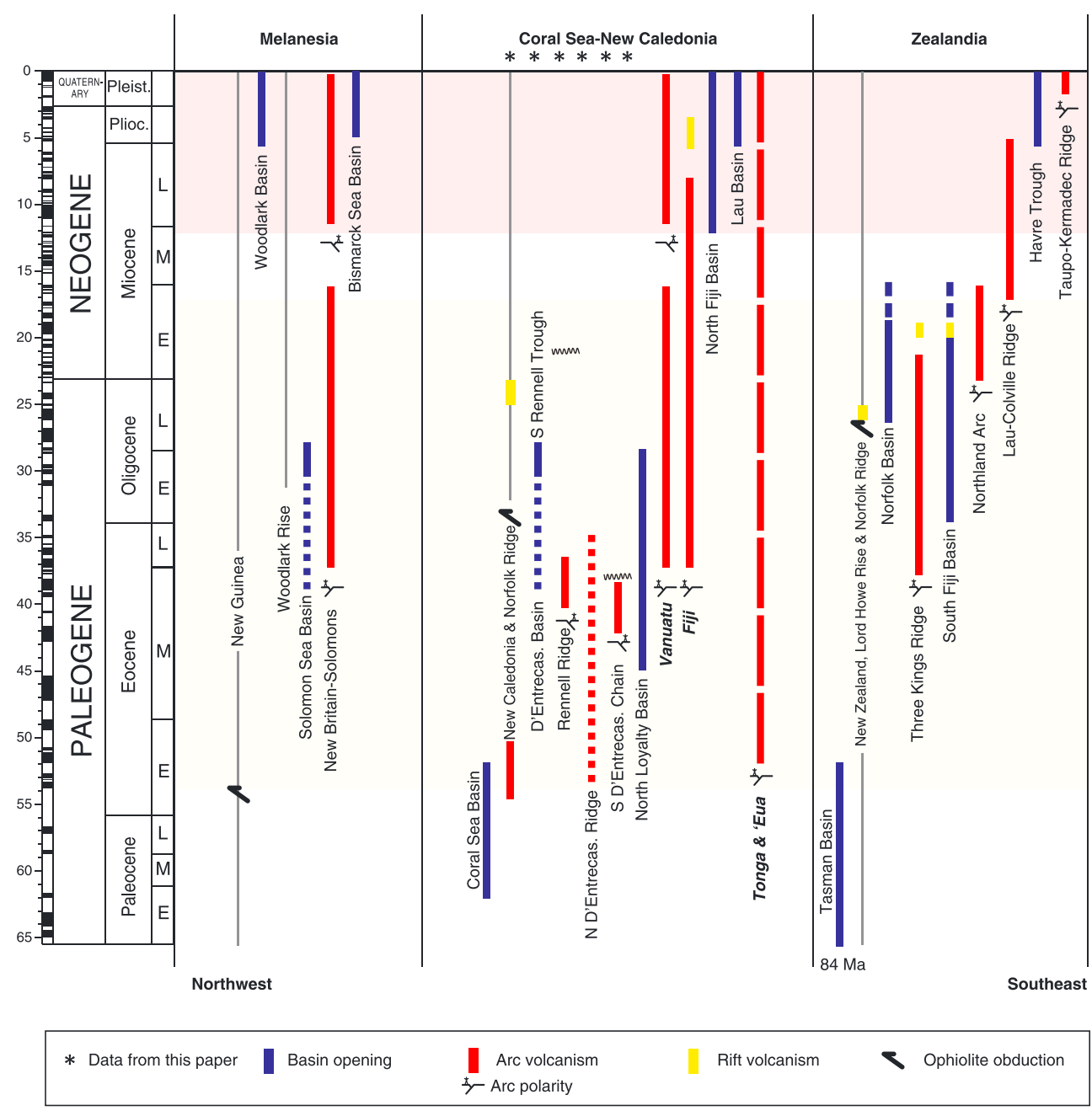

Figure 8. Age ranges of subduction-related magmatism, intraplate magmatism, and ocean basin and back-arc spreading between Melanesia and New Zealand. The ranges are not individual analytical precisions but represent demonstrable (solid) and inferred (dashed) ranges of magmatism in each area. Information from Kroenke and Rodda [1984], Joshima et al. [1987], Hall [2002], Mortimer et al. [2007], Whattam [2009], Herzer et al. [2011], Meffre et al. [2012], and this study.

\subsection{South Rennell Trough and Santa Cruz Basin}

The 28-29 Ma (early Oligocene) Ar-Ar ages obtained from four samples on both flanks of the South Rennell Trough (Figure 2) directly establish the feature as a constructional E-MORB like volcanic pile of Oligocene ageforming substrate to an intraoceanic rift graben (Figure 8). This result directly, confidently, and independently confirms the provisional Oligocene ridge interpretation first suggested on the basis of limited heat flow and bathymetry measurements by Larue et al. [1975, 1977] and Daniel et al. [1978]. Landmesser et al. [1975] interpreted the South Rennell Trough to be a fracture zone contemporaneous with 52-62 Ma Coral Sea opening. This now has to be rejected on the basis of our Oligocene bedrock ages; if crust did not form at the South Rennell Trough until circa $28 \mathrm{Ma}$, then it cannot have been deformed prior to that.

In its northeastern part, the South Rennell Trough lies toward the centre of the deep water ( $>4000 \mathrm{~m}$ ) Santa Cruz Basin. Here it is plausibly a symmetrical spreading ridge that split the formerly continguous Rennell Ridge and West Torres Plateau crust. Limited abyssal hill fabrics (Figure 2) support spreading perpendicular to the trough. Farther southwest, the South Rennell Trough does not occupy a position halfway between obviously rifted features (Figures 2 and 9a). The Mellish Rise lies to the west and the D'Entrecasteaux Basin, with some N-S abyssal hill spreading fabric, lies to the east. Despite the strong symmetrical topographic expression of the South Rennell Trough (Figure 3c), the spreading history of this southwestern region 


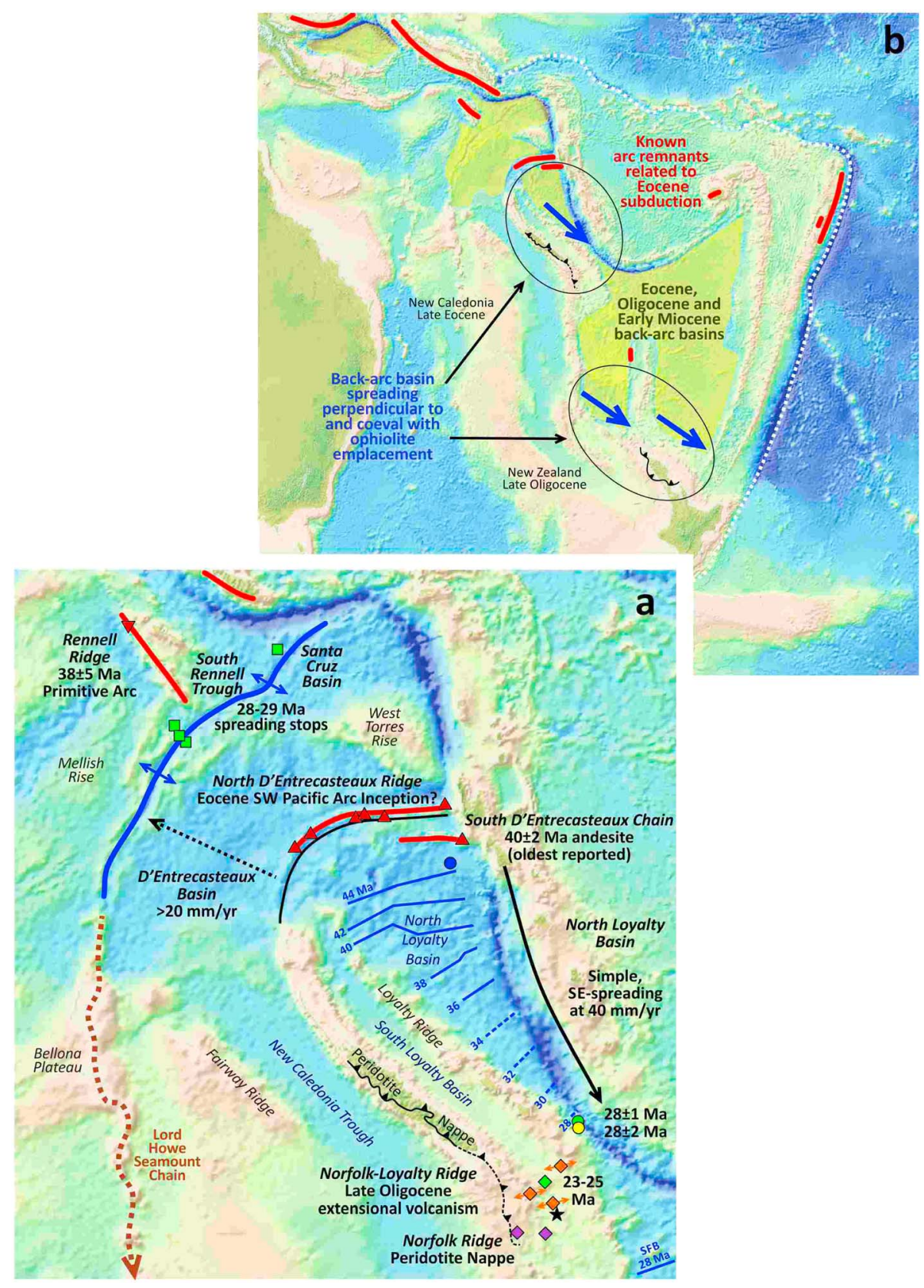

Figure 9. Summary figure showing major new results of this study. (a) Coral Sea-New Caledonia region and (b) wider southwest Pacific region. Symbols as in Figure 2.

prior to $29 \mathrm{Ma}$ is cryptic, particularly as the nature of crust underlying the Mellish Rise is unknown. The ORSTOM cruises did not sample very far from the main South Rennell Trough, and the age and (undoubtedly complex) spreading pattern in the D'Entrecasteaux Basin must remain speculative until further sampling and magnetic profiling are undertaken. Nonetheless, the E-MORB chemistry of the South Rennell Trough Oligocene lavas, with their minor slab geochemical signatures, mean that the South Rennell Trough and immediately surrounding basins can now be included as part of the group of Oligocene-early Miocene back-arc basins such as the South Fiji Basin and Solomon Sea Basin (Figures 1, 8, and 9b) [Joshima et al., 1987; Mortimer et al., 2007] and not one of the Late Cretaceous-Early Eocene basins as suggested by Lapouille [1982]. The South Rennell Trough is the most bathymetrically traceable fossil spreading ridge in the entire area of Figures 1 and 9. 


\subsection{North $D^{\prime}$ Entrecasteaux Ridge}

A single $49 \pm 10$ Ma basalt dredge from site GO324 in the western North D'Entrecasteaux Ridge gives an E-MORB back-arc basin-type composition. The other six dredge and drill sites on an $370 \mathrm{~km}$ strike length of the North D'Entrecasteaux Ridge are Eocene basalts that we interpret as primitive arc tholeiites (Figure 8) of similar composition to Early Arc Tholeiite suites described from Fiji and 'Eua by Todd et al. [2012].

Maillet et al. [1983] interpreted the same GEORSTOM sample data set as being early to late Eocene MORB-like basalts. Maillet et al.'s [1983] MORB interpretation was based on the elements Ti, Zr, and Y, whereas we have available high-precision Nb, Ta, and rare earth element analyses. Maillet et al. [1983] dated glasses using fission track methods; their ages had large corrections for uranium uptake as well as large errors. We also have had difficulty in precisely dating the North D'Entrecasteaux Ridge basalts by Ar-Ar methods due to their ultralow-K/Ca ratio. Nonetheless, our geochronological results are in broad agreement with those of Maillet et al. [1983].

At the eastern end of the North D'Entrecasteaux Chain, Coltorti et al. [1994] noted that the basalts from ODP828 had compositions transitional between MORB and island arc tholeiites and were comparable to basalts from small back-arc basins. The data of Coltorti et al. [1994] are entirely compatible with our own. Regional tectonic considerations led them to suggest that they may have formed in the fore arc of a putative Eocene island arc, the Loyalty-South D'Entrecasteaux Chain. Coltorti et al. [1994] refer to middle Eocene (40-48 Ma) planktonic foraminifera in the breccia of ODP829, and this must be regarded as the authoritative age on these rocks. As such, our $>27$ Ma age for P78814 and Rex's [1994] Miocene K-Ar ages are minima related to hydrothermal alteration.

Maillet et al. [1983] emphasized that the North D'Entrecasteaux Ridge was fundamentally a structural feature -they dredged horsts (Figure 3). Whatever its protolith, the dredged rocks have been exhumed and modified by dip- and likely strike-slip deformation. Based on their available bathymetric data, Maillet et al. [1983, Figure 3] postulated a possible cross-fault offset in the North D'Entrecasteaux Ridge between sites. However, the modern satellite gravity-based maps show continuity of the ridge indicating that the postulated fault of Maillet et al. [1983] does not exist.

In summary, the volcanic rocks of the North D'Entrecasteaux Ridge give an Eocene age, but we cannot say precisely what part of the Eocene. It must also be admitted that without the Fiji and 'Eua data set of Todd et al. [2012], the $>1 \mathrm{wt} \% \mathrm{TiO}_{2}$ content of the North D'Entrecasteaux basalts would probably have led us to interpret them as back-arc basin basalts instead of primitive arc tholeiites. Because the ridge is primarily a structural feature [Maillet et al., 1983], and the rocks are so low in radiogenic parent isotopes, satisfactory resolution of the age and tectonic setting of the North D'Entrecasteaux Ridge basement must await further sampling and study.

\subsection{Bougainville Guyot}

Baker et al. [1994] described the petrology and geochemistry of a $125 \mathrm{~m}$ thick sequence of andesitic volcanic breccia basement of Bougainville Guyot beneath a thick carbonate cap (unconformity at 727 $\mathrm{m}$ below seafloor (bsf)). To date, there has been ongoing uncertainty over the age of the volcanic breccias in ODP831. Whole-rock K-Ar ages obtained by Rex [1994] were 27 1 Ma (from $766 \mathrm{~m}$ bsf) and $37 \pm 1 \mathrm{Ma}$ (from $845 \mathrm{~m}$ bsf) with the former interpreted as an alteration age and the latter as stratigraphic age by Baker et al. [1994]. Our $40 \pm 2$ Ma Ar-Ar plagioclase age from an andesite breccia clast from a higher stratigraphic position than Rex's samples (746-756 m bsf) is slightly older, and we believe a superior and more reliable dating of the youngest precarbonate volcanism on Bougainville Guyot. This late middle Eocene exactly matches the age of andesitic clastic rocks in DSDP 286, $75 \mathrm{~km}$ distant [Stoeser, 1975].

According to some models [e.g., Greene and Collot, 1994], the South D'Entrecasteaux Chain represents an extinct (Paleocene-Eocene) subduction-related volcanic arc and the paleotrench is represented by the faultcontrolled, deep bathymetric lows either side of the North D'Entrecasteaux Ridge. If this is the case, then the arc-trench gap is unreasonably narrow, at $50-75 \mathrm{~km}$, again pointing to substantial postvolcanic structural modification of the entire D'Entrecasteaux Ridge. 


\subsection{Rennell Ridge}

From the water depth and structural position of the GO301 dredge site, it is probable that the two dredged basalts are fundamentally part of the Rennell Ridge rather than the Rennell Basin. The seismic profiles of Landmesser et al. [1975] and Daniel et al. [1978] both show what looks like a stepped, faulted margin between the two features. In the absence of any more information, we regard the GO301 site as a sampling of deep Rennell Ridge stratigraphy beneath the early Miocene carbonate reef.

The $38 \pm 5$ Ma primitive arc tholeiite is permissibly similar in composition and age to the primitive arc tholeiites of the North D'Entrecasteaux Ridge. There is danger in speculating further on the basis of just one poorly dated and stratigraphically constrained sample. In particular, it is conceivable that the rock is some sort of back-arc basin crust, not a proper arc. However, if the match with the D'Entrecasteaux Ridge lavas is correct, then the Rennell Ridge may be one of many dispersed primitive Eocene arc segments in the southwest Pacific (Figure 9b).

\subsection{Norfolk Ridge}

The ORSTOM dredge samples from the northern Norfolk Ridge confirm that some of the onland geological units of New Caledonia continue down the North Norfolk Ridge. The occurrence of pyroxenite and serpentinized peridotite can be generally matched with the allochthonous peridotite nappe of New Caledonia. A further very specific correlation is provided by P78594, the dated leucotonalite at GO16. Granitoid dikes that cut the onland peridotite nappe have been dated at $53 \mathrm{Ma}$ [Cluzel et al., 2006, 2012], and many of these, like P78594, have trondhjemitic to adakitic compositions with depleted heavy rare earth elements and relatively high $\mathrm{Na} / \mathrm{K}$ ratios. The metasomatic alteration of $\mathrm{P} 78594$ precludes any rigorous interpretations of its geochemistry.

The single E-MORB sample from dredge site GO13 on the Norfolk Ridge (Figure 2) was not dated for this study. But it is geochemically quite different from the medium-high $\mathrm{K}$ basalts and andesites and shoshonites. We provisionally assign it to the Poya Terrane of New Caledonia [Eissen et al., 1998]. Poya Terrane is a structural nappe beneath the Peridotite Nappe and thus further extends another element of the geology of onland New Caledonia down the Norfolk Ridge.

The five analyzed potassic intraplate 23-25 Ma (Oligocene) lavas from the Norfolk Ridge (samples from GO5, $10,13,14$, and 16) have no known correlatives in New Caledonia. However postobduction $24 \mathrm{Ma}$ and $27 \mathrm{Ma}$ granitoid stocks do occur in New Caledonia [Paquette and Cluzel, 2007; Cluzel et al., 2005]. The most mafic of these samples is a gabbro from the Saint Louis body. Cluzel et al. [2005] argued for a subduction origin for these Oligocene granitoids, but the gabbro's steep multielement normalized pattern (Figure 5f) most closely resembles an intraplate tholeiite such as the BHVO (Hawaiian Volcano Observatory basalt) analytical standard. Except for negative $\mathrm{Nb}$ and Ta anomalies, the chemistry and age of the five North Norfolk Ridge basalts reasonably resemble the New Caledonia Oligocene gabbro-granite suite. We suggest that all these Oligocene igneous rocks in and near New Caledonia formed in an intraplate to extensional setting. Such an interpretation fits with the Oligocene and Miocene extension postulated for New Caledonia [Lagabrielle et al., 2005] and the South Fiji Basin to the south [Mortimer et al., 2007].

\section{Regional Implications}

\subsection{Oligocene Back-Arc Basins Between Zealandia and Melanesia}

Our 28-29 Ma ages from the South Rennell Trough establish that cessation of spreading in the D'Entrecasteaux and Santa Cruz basins occurred in the middle Oligocene. Thus, these back-arc basins were opening at the same time as the Solomon Sea Basin and the South Fiji basin (Figures 8 and 9b). All basins are being subducted under the Vanuatu-Solomons-New Britain Trench and were once much larger probably extending as far as the present day Vitiaz Trench Lineament.

\subsection{Eocene Subduction-Related Arcs}

We here address the significance of our new data in the light of recent tectonic models for the SW Pacific, particularly those by Herzer et al. [2011] and Meffre et al. [2012]. We like the model of Meffre et al. [2012] whereby Fiji, a site of primitive Eocene arc volcanism, occupies a place between New Caledonia and the South D'Entrecasteaux Chain. However, the way that Meffre et al. [2012, Figure 10] show this system becoming dismembered in the 35-50 Ma interval needs to be revised in the light of the protracted (16 Myr) 
unidirectional North Loyalty Basin spreading direction shown in this paper (Figure 9). In order to restore the two against each other, there would have to have been a conjugate component of 30-44 Ma spreading, i.e., full NE-SW spreading as well a triple junction, with a north striking, E-W spreading arm [Herzer et al., 2011]. Thus, the North Loyalty Basin would have been much wider and more complex prior to its subduction in the Vanuatu Trench.

The Eocene arc lavas of Bougainville Guyot are commonly regarded as the eastern end of the Loyalty Ridge [Crawford et al., 2003; Johnston, 2004; Schellart et al., 2006], but we question whether there is, or needs to be, a geological connection between the South D'Entrecasteaux Chain (SDC) and the main NE trending Loyalty Ridge. The $150 \mathrm{~km}$ long SDC is parallel to the magnetic lineations in the North Loyalty Basin (Figure 2), but there is a $200 \mathrm{~km}$ gap between the westernmost SDC seamount and the northernmost seamount in the NW trending linear Loyalty Ridge. The Loyalty Ridge is also perpendicular to the magnetic lineations in the North Loyalty Basin (Figure 9a), and the divergence in known and inferred magnetic anomaly azimuths is insufficient to support oroclinal bending as proposed by Johnston [2004]. Despite its repeated interpretation as an Eocene island arc [e.g., Crawford et al., 2003; Schellart et al., 2006; Cluzel et al., 2006], no subductionrelated lavas have yet been obtained from the main Loyalty Ridge. We are starting to think about SW Pacific tectonic models in which the Loyalty Ridge never necessarily had to be an Eocene arc but was a zone of epidodic intraplate volcanism focused along the continent-ocean boundary.

\subsection{Ophiolite Emplacement}

The major Paleogene geological events of New Caledonia as they relate to emplacement of the peridotite nappe have been summarized by Maurizot [2011] and Cluzel et al. [2012] as follows. Ages on preobduction granitoid dikes that intrude the peridotite are circa $56 \mathrm{Ma}$, high-P peak metamorphism occurred at circa $44 \mathrm{Ma}$ [U-Pb zircon rim ages] and exhumation of high-P rocks was complete by $34 \mathrm{Ma}$ (apatite fission track ages). The youngest preobduction autochthonous sediments are late Eocene (34-37 Ma) which is also the time interval in which flysch basins record influx of the first allochthon-related ultramafic detritus. Postobduction subsidence is first recorded by early Miocene limestones overlain by Nepoui Formation [Coudray, 1977]. As a discrete tectonic episode, the obduction "event" is regarded to have occurred from 34 to $37 \mathrm{Ma}$, but clearly, there were some significant precursors. Postobduction granitoid intrusions seal the ultramafic allochthon at circa $27 \mathrm{Ma}$.

Models of the obduction of the New Caledonia ophiolite are most often framed in terms of northeast dipping subduction of the Zealandia continental margin beneath a South Loyalty Basin fore arc and Loyalty Arc. In this construct, the basal thrust of the peridotite nappe (Figure 9a) is the old plate boundary. New Zealand style models of ophiolite emplacement involving southwest dipping subduction initiation have not seriously been considered for New Caledonia since Brothers and Blake [1973] nor has the North Loyalty Basin been incorporated into New Caledonia obduction models. Yet, as this paper shows, the basin seemingly opened at a constant rate during the time interval in which high-P metamorphism and allochthon emplacement occurred. Furthermore, the direction of Loyalty Basin opening was in a direction perpendicular to the peridotite nappe emplacement direction (Figures 9a and 9b). We have not yet developed a complete tectonic model to integrate these data, but we do note the intriguing similarity with the late Oligocene-early Miocene in New Zealand where Norfolk and South Fiji back-arc basin opening and shoshonitic volcanism also occurred during and after ophiolite emplacement, and basin opening was also perpendicular to the direction of allochthon movement and parallel to the continent-ocean boundary (Figure 9b) [Mortimer et al., 2007; Herzer et al., 2011]. The southeastward "sweep" of synallochthon and postallochthon back-arc basins fits with an overall model of Pacific slab rollback with rollback starting earlier in the north and propagating south. The mechanical connections of ophiolite emplacement with perpendicular back-arc basin opening clearly need to be explored.

\section{Conclusions}

The geochemical and geochronological results reported in this paper significantly increment the compositional and age framework of the region between Melanesia and Zealandia. Although there are many outstanding tectonic questions that our legacy sample data cannot directly address or answer, we have significantly progressed our tectonic knowledge of several basins and ridges. 
Poorly dated primitive arc tholeiites of Eocene age (34-56 Ma) are present along a $200 \mathrm{~km}$ strike length of the North D'Entrecasteaux Ridge and could once have been part of the initial magmatic front related to subduction inception between Tonga and the Marianas. Andesitic volcanism on Bougainville Guyot on the adjacent South D'Entrecasteaux Chain has been dated at $40 \pm 2 \mathrm{Ma}$. The South Rennell Trough is confidently identified as a 28-29 Ma (Early Oligocene) fossil back-arc basin spreading ridge although the earlier spreading history and kinematics of the D'Entrecasteaux and Santa Cruz basins remain cryptic. On the other side of the D'Entrecasteaux Ridge, $43 \mathrm{~mm} / \mathrm{yr}$ unidirectional spreading in the North Loyalty Basin took place from 28 to $44 \mathrm{Ma}$ (i.e., to younger ages than formerly recognized) and was parallel, not perpendicular, to the major structural grain of the New Caledonia ophiolite nappe trace and to the Loyalty Ridge. Medium- and high-potassium alkaline lavas of 23-25 Ma (late Oligocene) age on the northern Norfolk Ridge are an additional response to this eastward rollback of the Pacific trench across the South Fiji Basin.

\section{Acknowledgments}

We appreciate the work of the scientists and crew of R/V Noroit on the GEORSTOM cruise and on the Nautile SUBPSO dives without whom we would not have had samples to study. The staff at the IODP core repository gave excellent service to our core request. The location data on which this paper is based are listed in Table 1 of the main paper; raw geochemical and geochronological data are supplied in Tables S1-S3 in the supporting information. Technical help from Neville Orr, John Simes, and Belinda Smith Lyttle is appreciated. Discussions with Pierrick Rouillard and Julien Collot helped improve the paper. Sebastien Meffre and an anonymous referee are thanked for their reviews of the submitted manuscript. This study was funded through Ministry of Business Innovation and Employment core funding to GNS Science with support from the Fonds de Cooperation Economique, Sociale et Culturelle pour le Pacifique.

\section{References}

Baker, P. E., M. Coltorti, L. Briqueu, T. Hasenaka, E. Condliffe, and A. J. Crawford (1994), Petrology and composition of the volcanic basement of Bougainville Guyot, site 831, Proc. Ocean Drill. Program Sci. Results, 134, 363-373.

Ballard, J. R., J. M. Palin, I. S. Williams, and I. H. Campbell (2001), Two ages of porphyry intrusion resolved for the super-giant Chuquicamata copper deposit in northern Chile by ELA-ICP-MS and SHRIMP, Geology, 29, 383-386.

Bitoun, G., and J. Récy (1982), Origine et évolution du bassin des loyauté et de ses bordures après la mise en place de la série ophiolitique de Nouvelle-Calédonie, in Equipe de Géologie-Geophysique du Centre ORSTOM de Nouméa, Contribution à l'étude géodynamique du Sud-Ouest Pacifique, Trav. Doc. ORSTOM, vol. 147, pp. 505-539, ORSTOM, Paris.

Bourrouilh, F., G. Bizon, and P. Baumann (1976), La plateforme carbonatée de l'íle de Rennell (Salomon, Sud Ouest Pacific) est au minimum d'âge Miocéne moyen, C. R. Acad. Sci. Paris Ser. D, 282, 1921-1924.

Brothers, R. N., and M. C. Blake Jr. (1973), Tertiary plate tectonics and high pressure metamorphism in New Caledonia, Tectonophysics, 17, 337-358.

Cluzel, D., D. Bosch, J.-L. Paquette, Y. Lemennicier, P. Montjoie, and R.-P. Menot (2005), Late Oligocene post-obduction granitoids of New Caledonia: A case for reactivated subduction and slab break-off, Isl. Arc, 14, 254-271.

Cluzel, D., S. Meffre, P. Maurizot, and A. J. Crawford (2006), Earliest Eocene (53 Ma) convergence in the Southwest Pacific: Evidence from preobduction dikes in the ophiolite of New Caledonia, Terra Nova, 18, 395-402.

Cluzel, D., F. Jourdan, S. Meffre, P. Maurizot, and S. Lesimple (2012), The metamorphic sole of New Caledonia ophiolite: ${ }^{40} \mathrm{Ar} /{ }^{39} \mathrm{Ar}, \mathrm{U}-\mathrm{Pb}$ and geochemical evidence for subduction inception at a spreading ridge, Tectonics, 31, TC3016, doi:10.1029/2011TC0033085.

Coleman, P. J., and G. H. Packham (1976), The Melanesian borderlands and India-Pacific plates' boundary, Earth Sci. Rev., 12, $197-233$.

Collot, J., Y. Lafoy, and L. Geli (2011), Structural provinces of the southwest Pacific. Map and explanatory notes, Geological Survey of New Caledonia, Nouméa.

Collot, J.-Y., S. Lallemand, B. Pelletier, J.-P. Eissen, G. Glaçon, M. A. Fisher, H. G. Greene, J. Boulin, J. Daniel, and M. Monzier (1992), Geology of the d'Entrecasteaux-New Hebrides arc collision zone: Results from a deep submersible survey, Tectonophysics, 212, $213-241$.

Coltorti, M., T. Hasenaka, L. Briqueu, R. E. Baker, and F. Siena (1994), Petrology and magmatic affinity of the north D'Entrecasteaux Ridge, central New Hebrides Trench, site 828, Proc. Ocean Drill. Program Sci. Results, 134, 353-362.

Coudray, J. (1977), The main events of the sedimentary and structural history of New Caledonia from the Oligocene to the present day, International Symposium on Geodynamics in South-West Pacific, Noumea 1976. Editions Technip, Paris, pp. 217-228.

Crawford, A. J., S. Meffre, and P. A. Symonds (2003), 120 to 0 Ma tectonic evolution of the southwest Pacific and analogous geological evolution of the 600 to 220 Ma Tasman Fold Belt System, Geol. Soc. Am. Spec. Pap., 372, 383-403.

Dalrymple, G. B., and W. A. Duffield (1988), High precision ${ }^{40} \mathrm{Ar} /{ }^{39} \mathrm{Ar}$ dating of Oligocene rhyolites from the Mogollon-Datil volcanic field using a continuous laser system, Geophys. Res. Lett., 15, 463-466, doi:10.1029/GL015i005p00463.

Daniel, J., F. Dugas, J. Dupont, C. Jouannic, J. Launay, M. Monzier, and J. Récy (1976), La zone charniere Nouvelle Calédonie-Ride De Norfolk (S.W. Pacifique)-Resultats de dragages et interpretation, Cah. ORSTOM Geol., 8, 95-105.

Daniel, J., C. Jouannic, B. M. Larue, and J. Récy (1977), Interpretation of d'Entrecasteaux zone (north of New Caledonia), International Symposium on Geodynamics in the southwest Pacific, Nouméa 1976. Editions Technip, Paris, pp. 117-124.

Daniel, J., C. Jouannic, B. M. Larue, and J. Récy (1978), Marine Geology of Eastern Coral Sea (Eastern Margin of Indo-Australian Plate, North of New Caledonia), South Pac. Mar. Geol. Notes, vol. 1, pp. 81-94, CCOP-SOPAC, Suva, Fiji.

Eissen, J.-P., A. J. Crawford, J. Cotten, S. Meffre, H. Bellon, and M. Delaune (1998), Geochemistry and tectonic significance of basalts in the Poya Terrane, New Caledonia, Tectonophysics, 284, 203-219.

Gaina, C., R. D. Müller, J.-Y. Royer, and P. Symonds (1999), Evolution of the Louisiade triple junction, J. Geophys. Res., 104, 12,927-12,939, doi:10.1029/1999JB900038.

Gans, P. B. (1997), Large-magnitude Oligo-Miocene extension in southern Sonora: Implications for the tectonic evolution of northwest Mexico, Tectonics, 16, 388-408, doi:10.1029/97TC00496.

Gans, P. B., and W. A. Bohrson (1998), Suppression of volcanism during rapid extension in the Basin and Range Province, United States, Science, 279(5347), 66-68.

Greene, H. G., and J.-Y. Collot (1994), Ridge-arc collision: Timing and deformation determined by Leg 134 drilling, central New Hebrides island arc, Proc. Ocean Drill. Program Sci. Results, 134, 609-621.

Hall, R. (2002), Cenozoic geological and plate tectonic evolution of SE Asia and the SW Pacific: Computer-based reconstructions, model and animations, J. Asian Earth Sci., 20, 353-431.

Hergt, J. M., and J. D. Woodhead (2007), A critical evaluation of recent models for Lau-Tonga arc-backarc basin magmatic evolution, Chem. Geol., 245, 9-44.

Herzer, R. H., D. H. N. Barker, W. R. Roest, and N. Mortimer (2011), Oligocene-Miocene spreading history of the northern South Fiji Basin and implications for the evolution of the New Zealand plate boundary, Geochem. Geophys. Geosyst., 12, Q02004, doi:10.1029/2010GC003291.

Johnston, S. T. (2004), The New Caledonia-D'Entrecasteaux orocline and its role in clockwise rotation of the Vanuatu-New Hebrides Arc and formation of the North Fiji Basin, Geol. Soc. Am. Spec. Pap., 383, 225-236. 
Joshima, M., Y. Okuda, F. Murakami, K. Kishimoto, and E. Honza (1987), Age of the Solomon Sea Basin from magnetic lineations, Geo-Mar. Lett., 6, 229-234.

Kroenke, L. W., and P. Rodda (1984), Cenozoic tectonic development of the southwest Pacific. United Nations ESCAP, CCOP/SOPAC, Technical Bulletin, 6 .

Lagabrielle, Y., P. Maurizot, Y. Lafoy, G. Cabioch, B. Pelletier, M. Regnier, I. Wabete, and S. Calmanth (2005), Post-Eocene extensional tectonics in Southern New Caledonia (SW Pacific): Insights from onshore fault analysis and offshore seismic data, Tectonophysics, 403, 1-28.

Landmesser, C. W., J. E. Andrews, and G. Packham (1975), Aspects of the geology of the eastern Coral sea and the western New Hebrides basin, Initial Rep. Deep Sea Drill. Proj., 30, 647-662.

Lapouille, A. (1978), Southern New Hebrides Basin and western South Fiji Basin as a single marginal basin, Bull. Aust. Soc. Explor. Geophys., 9 , 130-133.

Lapouille, A. (1982), Etude des bassins marginaux fossiles du Sud-Ouest Pacifique: Bassin Nord D’Entrecasteaux, Bassin Nord-Loyaute, Bassin Sud-Fidjien, in Equipe de Geologie-Geophysique du Centre ORSTOM de Noumea, Contribution a l'Etude Geodynamique du Sud-Ouest Pacifique, Trav. Doc. ORSTOM, vol. 147, pp. 409-438, ORSTOM, Paris.

Larue, B. M., J. Daniel, J. Récy, and J. Dubois (1975), De 1'existence d'une zone d'expansion fossile dans l'est de la mer de Corail (Sud Ouest Pacifique), C. R. Acad. Sci. Paris Ser. D, 281, 1455-1458.

Larue, B. M., J. Daniel, C. Jouannic, and J. Récy (1977), The South Rennell trough: Evidence for a fossil spreading zone, International Symposium on Geodynamics in the southwest Pacific, Nouméa 1976. Editions Technip, Paris, pp. 51-61.

Le Bas, M. J., R. W. Le Maitre, A. Streckeisen, and B. Zanettin (1986), A chemical classification of volcanic rocks based on the total alkali silica diagram, J. Petrol., 27, 745-750.

Luyendyk, B. P., W. B. Bryan, and P. A. Jezek (1974), Shallow structure of the New Hebrides island arc, Geol. Soc. Am. Bull., 85, 1287-1300.

Maillet, P., M. Monzier, M. Sélo, and M. Storzer (1983), The D’Entrecasteaux Zone (Southwest Pacific): A petrological and geochronological reappraisal, Mar. Geol., 53, 179-197.

Maurizot, P. (2011), First sedimentary record of the pre-obduction convergence in New Caledonia: Formation of an Early Eocene accretionary complex in the north of Grande Terre and emplacement of the 'Montanges Blanches' nappe, Bull. Soc. Geol. Fr., 182, $479-491$.

Meffre, S., T. J. Falloon, A. J. Crawford, K. Hoernle, F. Hauff, R. A. Duncan, S. H. Bloomer, and D. J. Wright (2012), Basalts erupted along the Tongan fore arc during subduction initiation: Evidence from geochronology of dredged rocks from the Tonga fore arc and trench, Geochem. Geophys. Geosyst., 13, Q12003, doi:10.1029/2012GC004335.

Monzier, M. (1976), GEORSTOM III NORD. Rapport preliminaire sure les echantillons dragues. Part 1. ORSTOM, Nouméa, Nouvelle Calédonie.

Monzier, M. (1993), Un modèle de collision arc insulaire-ride océanique: Evolution sismo-tectonique et pétrologie des volcanites de la zone d'affrontement arc des Nouvelles-Hébrides-ride des Loyauté, Unpublished PhD thesis, I'Université Française du Pacifique.

Monzier, M., J. Boulin, J.-Y. Collot, J. Daniel, S. Lallemand, and B. Pelletier (1989), Premiers résultats des plongées Nautile de la campagne SUBPSO-I sur la zone de collision a ride des Loyauté arc des Nouvelles-Hébrides (Sud-Ouest Pacifique), C. R. Acad. Sci. Paris Ser., 2(309), 2069-2076.

Mortimer, N., R. H. Herzer, P. B. Gans, C. Laporte-Magoni, A. T. Calvert, and D. Bosch (2007), Oligocene-Miocene tectonic evolution of the South Fiji Basin and Northland Plateau, SW Pacific Ocean: Evidence from petrology and dating of dredged rocks, Mar. Geol., $237,1-24$.

Mortimer, N., P. B. Gans, F. Hauff, and D. H. N. Barker (2012), Paleocene MORB and OIB from the Resolution Ridge, Tasman Sea, Aust. J. Earth Sci., 59, 953-964.

Paquette, J.-L., and D. Cluzel (2007), U-Pb zircon dating of post-obduction volcanic-arc granitoids and a granulite-facies xenolith from New Caledonia. Inference on Southwest Pacific geodynamic models, Int. J. Earth Sci., 96, 613-622.

Pearce, J. A. (2008), Geochemical fingerprinting of oceanic basalts with applications to ophiolite classification and the search for Archean oceanic crust, Lithos, 100, 14-48.

Pearce, J. A., and R. J. Stern (2006), Origin of back-arc basin magmas: Trace element and isotope perspectives, in Back-Arc Spreading Systems: Geological, Biological, Chemical, and Physical Interactions, Geophys. Monogr. Ser., vol. 166, edited by D. M. Christie et al., pp. 63-86, AGU, Washington, D. C.

Pearce, N. J. G., W. T. Perkins, J. A. Westgate, M. P. Gorton, S. E. Jackson, C. R. Neal, and S. P. Chenery (1997), A compilation of new and published major and trace element data for NIST SRM 610 and NIST SRM 612 glass reference materials, Geostand. Newsl., 21, $115-144$.

Peate, D. W., J. A. Pearce, C. J. Hawkesworth, H. C. Colley, C. M. Edwards, and K. Hirose (1997), Geochemical variations in Vanuatu arc lavas: The role of subducted material and a variable mantle wedge composition, J. Petrol., 38, 1331-1358.

Pelletier, B., and J. M. Auzende (1996), Geometry and structure of the Vitiaz trench lineament (SW Pacific), Mar. Geophys. Res., 18, 305-335.

Price, R. C., L. E. Johnson, and A. J. Crawford (1990), Basalts of the North Fiji Basin: The generation of back arc basin magmas by mixing of depleted and enriched mantle sources, Contrib. Mineral. Petrol., 105, 101-121.

Récy, J., and J. Dupont (1982), Le sud-ouest du Pacifique: Données structurales. Notice Explicative 97, Carte à 1:12 000 000. ORSTOM, Paris. Récy, J., J. Daniel, B. Larue, and L. V. Hawkins (1975), De l'existence d'une zone de subduction fossile dans la region de Rennell (Sud-Ouest Pacifique), C. R. Acad. Sci. Paris Ser. D, 281, 489-492.

Rex, D. C. (1994), K-Ar age determinations of samples from Leg 134, Proc. Ocean Drill. Prog. Sci. Results, 134, $413-414$.

Ryan, W. B. F., et al. (2009), Global multi-resolution topography synthesis, Geochem. Geophys. Geosyst., 10, Q03014, doi:10.1029/2008GC002332.

Sandwell, D. T., and W. H. F. Smith (1997), Marine gravity anomaly from Geosat and ERS I satellite altimetry, J. Geophys. Res., 102, 10,039-10,054, doi:10.1029/96JB03223.

Schellart, W. P., G. S. Lister, and V. G. Toy (2006), A Late Cretaceous and Cenozoic reconstruction of the Southwest Pacific region: Tectonics controlled by subduction and slab rollback processes, Earth Sci. Rev., 76, 191-233.

Sdrolias, M., R. D. Müller, and C. Gaina (2003), Tectonic evolution of the southwest Pacific using constraints from backarc basins, Geol. Soc. Aust. Spec. Publ., 22, 343-359.

Shipboard Scientific Party (1975), Site 286, Initial Rep. Deep Sea Drill. Proj., 30, 69-91.

Shipboard Scientific Party (1994a), Site 828, Proc. Ocean Drill. Prog. Sci. Results, 134, 139-177.

Shipboard Scientific Party (1994b), Site 831, Proc. Ocean Drill. Prog. Sci. Results, 134, 317-386.

Stoeser, D. B. (1975), Igneous rocks from Leg 30 of the Deep Sea Drilling Project, Initial Rep. Deep Sea Drill. Proj., 30, $401-414$.

Sun, S.-S., and W. F. McDonough (1989), Chemical and isotopic systematics of oceanic basalts: Implications for mantle composition and processes, Geol. Soc. London Spec. Publ., 42, 313-345.

Terrill, A. (1975), East Australian margin and the western marginal basins: Depositional and tectonic patterns in the northern Lord Howe Rise-Mellish Rise area, Bull. Aust. Soc. Explor. Geophys., 6, 37-39.

Thompson, R. N. (1982), Magmatism of the British Tertiary Province, Scott. J. Geol., 18, 49-107. 
Todd, E., J. B. Gill, and J. A. Pearce (2012), A variably enriched mantle wedge and contrasting melt types during arc stages following subduction initiation in Fiji and Tonga, southwest Pacific, Earth Planet. Sci. Lett., 335-336, 180-194.

Weissel, J. K., and A. B. Watts (1979), Tectonic evolution of the Coral Sea basin, J. Geophys. Res., 84, 4572-4582, doi:10.1029/JB084iB09p04572.

Weissel, J. K., A. B. Watts, and A. Lapouille (1982), Evidence for late Paleocene to late Eocene seafloor spreading in the southern New Hebrides basin, Tectonophysics, 87, 234-251.

Whattam, S. A. (2009), Arc-continent collisional orogenesis in the SW Pacific and the nature, source and correlation of emplaced ophiolitic nappe components, Lithos, 113, 88-114, doi:10.1016/j.lithos.2008.11.009.

Whattam, S. A., J. Malpas, J. R. Ali, and I. E. M. Smith (2008), New SW Pacific tectonic model: Cyclical intraoceanic magmatic arc construction and near coeval emplacement along the Australia-Pacific margin in the Cenozoic, Geochem. Geophys. Geosyst., 9, Q03021, doi:10.1029/2007GC001710. 